Krzysztof Ignatowicz

Uniwersytet Warszawski

Radosław Kiejstut Kardaś

\title{
Wojna 44-dniowa: kolejna odsłona konfliktu o Górski Karabach ${ }^{236}$
}

$\mathrm{D}$ zień 27 września 2020 r. w historii konfliktu o Górski Karabach pomiędzy Armenią a Azerbejdżanem zapisał się jako początek nowego „gorącego” etapu sporu. Podczas gdy świat zmagał się z kolejną falą pandemii wywołaną wirusem SARS-CoV-2, tego dnia wzdłuż całej linii kontaktowej, rozdzielającej obszary kontrolowane przez Azerbejdżan od separatystycznej Republiki Górskiego Karabachu ${ }^{237}$ rozpoczęły się gwałtowne walki między Armenią a Azerbejdżanem. Pomimo, że starcia zbrojnego można było się spodziewać praktycznie w każdej chwili ${ }^{238}$ to zaskoczenie - zarówno wśród mediów, jak i ośrodków analitycznych - co do jego intensywności oraz skali było znaczne. Analizując początkową fazę konfliktu można zauważyć jak dobrze w pierwszych godzinach walk Azerowie przygotowani byli do prowadzenia nie tylko działań wojennych, ale również politycznych i informacyjnych. Z kolei Ormianie na początku starć sprawiali wrażenie zdezorientowanych, nieprzygotowanych na tak dynamicznie rozwijającą się sytuację i ewidentnie liczyli na wsparcie Rosji. W tym kontekście warto uwypuklić także interesującą sytuację w zakresie deklarowanego poparcia, faktycznego wsparcia i nieoczekiwanych sojuszy, jakie ujawniły się podczas zeszłorocznej wojny pomiędzy - wydawać by się mogło - państwami o sprzecznych interesach, jak miało to miejsce w odniesieniu do współpracy szyickiego Azerbejdżanu

\footnotetext{
${ }^{236}$ Wojna azersko-ormiańska z 2020 roku w Górskim Karabachu jest również określana jako wojna jesienna lub II wojna karabachska.

237 Należy odnotować, iż Republika Górskiego Karabachu jest nieuznawanym przez „społeczność międzynarodową" quasi-państwem. W tym kontekście interesującej analizy dokonał Krzysztof Fedorowicz. Zwraca on uwagę, że mimo braku uznania, Republika Górskiego Karabachu posiada realną i fizyczną zdolność do wypełniania podstawowych funkcji państwa dotyczących zapewnienia bezpieczeństwa wewnętrznego, porządku publicznego, ochrony terytorium, warunków socjalno-ekonomicznych związanych z pracą, ochroną zdrowia, oświatą a także budową i utrzymaniem infrastruktury, zob. K. Fedorowicz, Republika Górskiego Karabachu - atrybuty państwowości a realia polityczne, w: V. Serzhanova, J. Wilk, K. Nowak, J. Plis (red.), Problemy państw nieuznawanych we wspótczesnym świecie, Warszawa 2019.

${ }^{238}$ Pomimo zawarcia porozumienia w 1994 r. pomiędzy Armenią i Azerbejdżanem, wielokrotnie dochodziło do starć zbrojnych.
} 
z jednej strony $\mathrm{z}$ Izraelem, a $\mathrm{z}$ drugiej $\mathrm{z}$ Turcją - państwami pozostającymi ze sobą w konflikcie ${ }^{239}$.

Przedmiotem analizy jest konflikt o Górski Karabach. Rozważania autorów rozpoczyna prezentacja jego genezy wraz z krótkim rysem historycznym. Następnie analizie poddano najnowszy etap walk pomiędzy Armenią a Azerbejdżanem, zwracając uwagę na międzynarodowy wymiar konfliktu ze szczególnym uwzględnieniem pozycji Rosji. Ostatnią część poświęcono rosyjskim siłom pokojowym i konsekwencjom związanym z obecnością tego kontyngentu dla regionu.

\section{Geneza i krótki rys historyczny sporu o Górski Karabach}

Źródła konfliktu azersko-ormiańskiego sięgają początków XX stulecia ${ }^{240}$, kiedy Górski Karabach stał się polem rywalizacji o ten obszar pomiędzy Armenią a Azerbejdżanem. Z uwagi na złożoną historię etniczną regionu pojawienie się sporów na tym tle było jedynie kwestią czasu. Wojciech Górecki, analityk Ośrodka Studiów Wschodnich, zwraca uwagę, że pierwsze niepokoje miały miejsce jeszcze za czasów Cesarstwa Rosyjskiego w latach 19051906. Natomiast wydarzeniem, które wzmocniło niechęć pomiędzy dwoma narodami była rzeź dokonana przez - bliskich kulturowo Azerom - Turków na Ormianach w 1915 r. ${ }^{241}$ Spór o status Górskiego Karabachu nabrał nowej dynamiki z jednej strony wraz z przejęciem władzy przez bolszewików, a z drugiej - propozycjami związanymi z zakończeniem I wojny światowej.

W konsekwencji umacniania się władzy bolszewików większego tempa nabrał proces kształtowania granic republik wchodzących w skład Związku Socjalistycznych Republik Radzieckich ${ }^{242}$. Przemysław Adamczewski zwraca uwagę, że w 1923 r., po dwóch latach prac różnych komisji, prezydium Komitetu Centralnego Komunistycznej Partii

\footnotetext{
${ }^{239}$ Z. Parafianowicz, Wojna o Karabach i sojusze, które nie miaty prawa zaistnieć, https://www.gazetaprawna.pl/wiadomosci/artykuly/1496259,parafianowicz-wojna-o-karabach-i-sojusze-ktorenie-mialy-prawa-zaistniec.html (01.05.2021).

${ }^{240} \mathrm{~W}$. Górecki wskazuje, że praźródeł napięć można już upatrywać w pierwszej dekadzie XIX stulecia, które były wynikiem zmian demograficznych na Kaukazie Południowym po przyłączeniu go do Rosji. W wyniku migracji z Persji i Turcji w regionie wzrósł procentowy udział chrześcijańskich Ormian, co w połączeniu z faworyzowaniem ich przez carską administrację wywoływało konflikty $\mathrm{z}$ ludnością azerbejdżańsko-muzułmańską. W następnych dekadach tarcia te znacznie wyostrzyło i pogłębiło zderzenie rozwijających się ruchów narodowych i nowoczesnych nacjonalizmów (ormiańskiego i azerbejdżańskiego), stymulowanych procesami modernizacyjnymi. Zob. W. Górecki, Kaukaski węzet gordyjski. Konflikt o Górski Karabach, „Raport OSW”, Maj 2020, s. 55.

${ }^{241}$ W. Górecki, Kaukaski węzet... s. 55.

${ }^{242}$ Zob. J. Zieliński, Konflikt o Górski Karabach i próby jego rozwiq̨ania, Annales Universitatis Paedagogicae Cracoviensis, Studia Politologica, 2014, nr 12.
} 
Azerbejdżanu zdecydowało się, aby z górskiej części Karabachu utworzyć Autonomiczny Obwód Górskiego Karabachu ${ }^{243}$. Później w 1936 r. nastąpiła zmiana nazwy na GórskoKarabachski Obwód Autonomiczny, natomiast nie wiązało się to z żadnymi innymi zmianami.

Przez kolejne dziesięciolecia istnienia ZSRR nie odnotowywano walk o charakterze zbrojnym pomiędzy Armeńską SRR a Azerską SRR, co było związane z silną koncentracją władzy na poziomie centralnym w Moskwie. Sytuacja zaczęła się zmieniać wraz ze słabnięciem Związku Radzieckiego i zainicjowanym w połowie lat 80-tych XX w. przez Michaiła Gorbaczowa programem reform pierestrojki i głoszonymi hasłami glasnosti. Proces zmian w wymiarze gospodarczym był tak gwałtowny, że władze w Moskwie nie były w stanie nad nim zapanować. Dodatkowo, na wydarzenia społeczno-ekonomiczne nałożyły się kwestie polityczne i narodowościowe, które w wielu przypadkach doprowadziły do starć na tle etnicznym ${ }^{244}$. Wśród nich znalazły się walki o Górski Karabach w latach 1987-1991. Bliższa analiza sporu o Górski Karabach pozwala wyróżnić kilka jego etapów. Za cezurę można przyjąć stopień intensyfikacji działań wojennych od momentu ich podjęcia do wstrzymywania walk.

Pierwszy etap eskalacji konfliktu obejmuje lata $1987^{245}-1991$, kiedy to w konsekwencji postępującego „rozkładu” ZSRR uwidoczniły się konflikty pomiędzy poszczególnymi narodami ${ }^{246}$. Za początek tego etapu można uznać wydarzenia z października

243 P. Adamczewski, Przywództwo polityczne na poradzieckim obszarze o nieustalonym statusie. Casus Górskiego Karabachu, w: T. Bodio (red.), Kaukaz: mechanizmy legitymacji i funkcjonowania elit politycznych, t. 7, Warszawa 2012, s. 164.

${ }^{244}$ Tadeusz Bodio przytacza dane za V. Amelin z których wynika, że w latach 1988-1987 takich konfliktów było ponad 150, z czego w 20 z nich były ofiary śmiertelne. Zob. T. Bodio, Etnokracja w Azji Centralnej, w: T. Bodio, W. Jakubowski (red.), Przywództwo i elity polityczne w krajach WNP, t. 2, Warszawa 2010, s. 222.

${ }^{245}$ Szymon Kardaś w swojej periodyzacji konfliktu o Górski Karabach jako początek intensyfikacji sporu przyjął rok 1988. Zob. Sz. Kardaś, Rola elit politycznych w konfliktach na obszarze WNP (na przykładzie armeńskoazerbejdzańskiego sporu o Górski Karabach w: T. Bodio (red.), Kaukaz: mechanizmy legitymacji $i$ funkcjonowania elit politycznych, Tom 7, Warszawa 2012, s. 417. W kontekście początków eskalacji konfliktu podobnego zdania jest Siergiej Markiedonow. Zob. С. Маркедонов, Tридцать лет нагорно-карабахского конфликта: основные этапы и перспективы урегулирования, «Постсоветские исследования» 2018, t. 1. № 2, s. 131 .

${ }^{246}$ Warto w tym miejscu odnotować, że konflikt o Górski Karabach na przełomie lat osiemdziesiątych i dziewięćdziesiątych XX odegrał znaczącą rolę w rozpadzie ZSRR i procesu usamodzielniania się republik związkowych i rodzących się ruchów narodowych i nacjonalistycznych. W kontekście upadku ZSRR zwraca uwagę teza Hélène Carrère-d'Encausse, wskazująca, iż Związek Sowiecki rozpadł się w wyniku ,podwójnego oddziaływania sił ekonomii i nacjonalizmu". Cyt. za: E. M. Thompson, Trubadurzy imperium. Literatura rosyjska i kolonializm, tłum. A. Sierszulska, Kraków 2000, s. 5, Horyzonty Nowoczesności, t. 8. Interesującej analizy w zakresie czynnika nacjonalizmu w azersko-ormiańskim sporze wokół Górskiego Karabachu dokonała Natalia Konarzewska. Zwraca uwagę, że mobilizacja nacjonalistyczna odegrała w azersko-ormiańskim sporze istotną rolę, zaś dziedzictwo radzieckiego systemu instytucjonalizacji oraz terytorializacji etniczności ułatwiło 
1987 r. kiedy doszło do pierwszych starć w Armenii. W ich wyniku kilkuset Azerbejdżan musiało uciekać do Azerbejdżanu. Spór zaczął nabierać tempa w kolejnych miesiącach i eskalował w lutym 1988 r., doprowadzając do pogromów Ormian w Sumgaicie ${ }^{247}$. Wydarzeniami, które pogłębiały spór były decyzje Rady Obwodowej GKOA z lipca 1988 r. o wyjściu obwodu z Azerbejdżanu oraz Rady Najwyższej Armenii z grudnia 1989 r., dotyczące zjednoczenia GKOA i Armeńskiej SRR ${ }^{248}$. Kolejne miesiące to różnego rodzaju zdarzenia, których dopuszczali się zarówno Ormianie, jak i Azerbejdżanie ${ }^{249}$. Podejmowano też próby ustabilizowania sytuacji i zmniejszenia napięcia pomiędzy zwaśniony stronami. Nie zakończyły się jednak one sukcesem. Jacek Zieliński przypomina, że wraz upadającym Związkiem Radzieckim władze autonomii postanowiły skorzystać z prawa do samookreślenia i wybrać tzw. trzecie rozwiązanie - nie pozostawać ani w składzie Armenii, ani Azerbejdżanu. 2 września 1991 r. władze Górskiego Karabachu uchwaliły Deklarację „O powstaniu Republiki Górskiego Karabachu”250. Azerbejdżan nie uznał tego aktu i rozpoczął ostrzał Stepanakertu, rozpoczynając działania zbrojne i tym samym walkę o Górski Karabach, likwidując w praktyce autonomię obwodu ${ }^{251}$. W grudniu tego samego roku ogłoszono referendum w którym wzięło udział 82,2\% uprawnionych z czego 99,89\% ludności karabachskiej opowiedziało się za niepodległością. Następnie ogłoszono utworzenie Republiki Górskiego Karabachu, uchwalając Deklarację „O państwowej niepodległości Republiki Górskiego Karabachu”252. Siergiej Markedonow zwraca uwagę, że był to okres konfliktu wewnątrzpaństwowego między dwiema republikami związkowymi oraz regionem autonomicznym po stronie jednej z republik, w ramach jednego państwa ZSRR. W tamtym okresie dominującym żądaniem strony ormiańskiej było zjednoczenie GKOA z Armeńską

\footnotetext{
artykulację i realizację postulatów narodowościowych. Wskazuje także na to, iż ormiańskie żądania dotyczące enklawy miały znaczny wpływ na rozwój azerskiego nacjonalizmu. Zob. N. Konarzewska Rola nacjonalizmu w azersko-ormiańskim sporze wokót Górskiego Karabachu, Studia politologiczne, 2012, vol. 23.

${ }^{247}$ W. Górecki zaznacza, że przebywające w mieście wojsko i milicja nie interweniowały, wskazując, iż uprawdopodobnia to hipotezę, że pogromy te były wynikiem prowokacji - mogli za nią stać konserwatywni przeciwnicy Michaiła Gorbaczowa wśród radzieckich władz. Zob. W. Górecki, Kaukaski węzeł..., s. 56.

${ }^{248}$ Zbigniew Rokita wskazuje, iż przyłączenie Górskiego Karabachu nie miało mocy prawnej, bowiem w zgodzie z prawodawstwem związkowym konieczna była zgoda władz centralnych na jakąkolwiek zmianę administracyjną. Zob. Z. Rokita, Historia konfliktu górskokarabaskiego i jego miejsce w polityce zagranicznej Federacji Rosyjskiej. Pisma Humanistyczne 7, 2010, s. 139.

${ }^{249}$ Ibidem.

${ }^{250}$ J. Zieliński, Konflikt o Górski Karabach i próby jego rozwiąania, Annales Universitatis Paedagogicae Cracoviensis. Studia Politologica" 2014, nr 12, s. 152.

${ }^{251}$ Zob. Z. Rokita, op. cit., s. 139.

${ }^{252}$ Zob. J. Zieliński, op. cit. s. 152
} 
SRR. Z kolei dla strony azerbejdżańskiej głównym priorytetem było zachowanie terytorialnej integralności republiki ${ }^{253}$.

Drugi etap przypada na lata 1991-1994 i obejmuje wojnę pomiędzy Armenią i Azerbejdżanem, która toczyła się w latach 1992-1994. Geneza konfliktu sięga jeszcze końca roku 1991, kiedy to nastąpiła eskalacja napięcia. Natomiast za początek wojny przyjmuje się rok 1992, kiedy walki nabrały regularnego charakteru. Bliższa analiza wojny pozwala wydzielić jej kilka faz. W pierwszej, trwającej od lutego do maja, siły ormiańskie przejęły kontrolę nad całym byłym obwodem. Ponadto Ormianie zajęli Laczyn wraz z tzw. korytarzem laczyńskim - strategicznie ważną drogą łączącą Karabach z Armenią. Druga faza wiąże się z kontrofensywą sił Azerbejdżanu, które od czerwca do sierpnia zdobyły około połowę terytorium Karabachu, a także ziemie leżące na północ od byłego GKOA. Kolejna faza to ponowna przewaga sił armeńskich i odzyskiwanie utraconych pozycji oraz zmniejszenie dynamiki działań Azerbejdżanu ${ }^{254}$. Czwarta faza obejmuje zintensyfikowanie działań Armenii, które rozpoczęły się w lutym 1993 r. i trwały do października 1993 r. Sukcesy militarne doprowadziły do zajęcia prawie całego GKOA, a także Kelbadżar oraz azerbejdżańskich ziem położonych na wschód i na południe od byłego GKOA. Piąta faza wiąże się z grudniową ofensywą sił Azerbejdżanu, która zakończyła się porażką. W marcu 1994 r. Azerbejdżan zdecydował się na wycofanie żołnierzy, natomiast kwietniowa kontrofensywa sił Armenii nie doprowadziła do istotnej zmiany. Ówczesny prezydent Azerbejdżanu Hejdar Alijew zdecydował się na rozpoczęcie rozmów, przy udziale Rosji, WNP oraz Mińskiej Grupy KBWE (następnie OBWE). Ostatecznie Ormianie zwyciężyli w wojnie uzyskując kontrolę nad większą częścią obwodu i opanowując także przyległych terytoriów - rejon laczyński, dżebrailski, kubatliński, zangilański i kelbadżarski, a także częściowo rejony agdamski i fizuliński ${ }^{255}$. Koniec tego etapu wiąże się z podpisaniem rozejmu 12 maja 1994 r. pomiędzy Górskim Karabachem i Armenią a Azerbejdżanem. Warto odnotować, że wojna wiązała się z dramatem setek tysięcy ludzi, którzy musieli opuścić swoje domy ${ }^{256}$, jak również $\mathrm{z}$ szeregiem powstałych utrudnień w wymiarze transportowokomunikacyjnym, czy też realną utratą korzyści z potencjalnej współpracy gospodarczej.

\footnotetext{
${ }^{253}$ C. Маркедонов, Тридиать лет..., s. 131.

254 W. Górecki podkreśla, że wpływ na to miał konflikt w azerbejdżańskim dowództwie. Jeden $\mathrm{z}$ zaangażowanych weń komendantów, Suret Husejnow, po niepowodzeniach na froncie w pierwszych dniach 1993 r. wyprowadził wierne sobie oddziały do Gandży, osłabiając w ten sposób azerbejdżańską armię.

255 Zob. C. Маркедонов, op. cit., s. 132.

${ }^{256}$ Szacuje się, w wyniku wojny liczba osób przesiedlonych wyniosła: ok. 500 tys. Azerbejdżan z Górskiego Karabachu i siedmiu przyległych rejonów, ok. 350 tys. Ormian z Azerbejdżanu i 200 tys. Azerbejdżan z
} 
Kolejny etap obejmuje lata $1994-2016^{257}$ i rozpoczą się od podpisania porozumienia kończącego wojnę i przebiegał w dwóch fazach. Pierwsza, trwająca do 2004 r., cechowała się względnym spokojem i koncentracją na wymiarze politycznym i dyplomatycznym ${ }^{258}$. Wojciech Górecki zwraca uwagę, że był to również czas budowy struktur państwowych w obu republikach, sprzyjających stabilizacji sytuacji ${ }^{259}$. Analiza wydarzeń po zakończeniu wojny do pierwszych lat nowego milenium pokazuje, że pomiędzy Armenią a Azerbejdżanem rzeczywiście nie dochodziło do ostrych i intensywnych walk, choć zdarzyły się incydenty zbrojne. Druga faza obejmuje lata 2004-2016. Za jej symboliczny początek można uznać zabójstwo Gurgena Margarjana, ormiańskiego oficera przez azerbejdżańskiego oficera Ramila Safarowa, które miało miejsce 19 lutego 2004 r. w Budapeszcie podczas kursów językowych organizowanych przez NATO w ramach programu Partnerstwo dla Pokoju ${ }^{260}$. Po tym wydarzeniu, można było zaobserwować rosnące napięcie, którego rezultatem była zwiększająca się liczba incydentów zbrojnych. Wiązało się to m.in. z coraz większym ograniczeniem kontaktów pomiędzy mieszkańcami Azerbejdżanu i Armenii. Nie bez znaczenia była, na co zwraca uwagę Wojciech Górecki, także antyormiańska propaganda w Azerbejdżanie $\mathrm{i}$ antyazerbejdżańska w Armenii oraz początek prezydentury Ilhama Alijewa. Należy wskazać, że podejmowane były zewnętrzne, międzynarodowe próby załagodzenia lub rozwiązania konfliktu - m.in. przez Grupę Mińską OBWE w 2007 r. ${ }^{261}$ czy Rosję w 2008 r. ${ }^{262}$, jednak ostatecznie nie przyniosły one oczekiwanych rezultatów i konflikt

Armenii. Zob. Сможет ли Азербайджан вернуть своих беженцев в Карабах?, https://www.bbc.com/russian/news-56660532 (3.05.2021).

${ }^{257}$ Podobne ujęcie czasowe danego etapu prezentuje C. Маркедонов. Zob. С. Маркедонов, К. Вали, Х. Керим, Слом статус-кво и международное измерение кризиса в Нагорном Карабахе. Доклад Международного дискуссионного клуба «Валдай», Декабрь 2020, s. 7, https://ru.valdaiclub.com/files/36258/ Z kolei W. Górecki wydziela dwa etapy: pierwszy obejmujący lata 1994-2003 to „konflikt o niskiej intensywności”, drugi przypada na lata 2003-2016 i jest określony jako „stopniowa eskalacja napięcia”. Zob. W. Górecki, Kaukaski węzet..., s. 59-60.

258 Zob. С. Маркедонов, Тридчать лет..., s. 133.

${ }^{259}$ W. Górecki, Kaukaski węzet..., s. 59.

260 Zob. А. Бородихин, Топор в ЕСПЧ. Суд вынес решение поделу азербайджанского офичера, зарубившего спящего сослуживца-армянина, https://zona.media/article/2020/05/26/axe (3.05.2021)

${ }^{261} \mathrm{~W}$ listopadzie 2007 roku na spotkaniu państw członkowskich OBWE w stolicy Hiszpanii zostały opracowane „Zasady madryckie” - lista podstawowych zapisów określających proces pokojowego rozwiązania konfliktu w Górskim Karabachu między Armenią a Azerbejdżanem. Obejmowały one cztery kluczowe działania: wycofanie Ormian z obszarów wokół Górskiego Karabachu (wojska ormiańskie faktycznie zajmowały obszar wykraczający poza granice Górskiego Karabachu); pozostawienie Armenii korytarza łączącego ją z Górskim Karabachem (korytarz laczyński); określenie przyszłego statusu Górskiego Karabachu w drodze referendalnej; powrót uchodźców, zob. "Мадридские принцииы", https://www.kavkaz-uzel.eu/articles/160309/ (3.05.2021)

${ }^{262}$ W listopadzie 2008 r. na zamku Meiendorf prezydenci Federacji Rosyjskiej, Azerbejdżanu i Armenii podpisali pięciopunktową deklarację, która stała się pierwszą od 1994 r., zawartą przez bezpośrednich uczestników konfliktu. W dokumencie zobowiązywano się m.in. do przyczyniania się do poprawy sytuacji na 
się nasilał. Szczególny wzrost napięcia na linii Azerbejdżan - Armenia spowodowało W sierpniu 2012 r. ułaskawienie przez prezydenta Azerbejdżanu, a następnie uhonorowanie Ramila Safarowa, skazanego wcześniej na Węgrzech na dożywocie za zabicie żołnierza armeńskiego podczas kursu $\mathrm{NATO}^{263}$. W następnym okresie doszło do dalszej eskalacji konfliktu i wzmożenia działań zbrojnych, które jak wskazuje Wojciech Górecki miały coraz częściej charakter nie tylko snajperski czy dywersyjny, ale także artyleryjski ${ }^{264}$.

Za początek czwartego etapu przyjmuje się datę 2 kwietnia 2016 r., kiedy to doszło do intensywnych walk. Straty osobowe oszacowano na około 100 zabitych i kilkuset rannych (po obu stronach). W wyniku walk Azerbejdżanowi udało się w niewielkim stopniu zmienić linię frontu na własną korzyść. Za koniec tego etapu określanego miałem wojny czterodniowej uznaje się 5 kwietnia 2016 r., kiedy to przy udziale Rosji doszło do mediacji pomiędzy Armenią i Azerbejdżanem. Głównym wygranym tych wydarzeń okazała się Rosja. Moskwa przez kilka dni zachowywała powściągliwość, następnie zaś w ciągu paru godzin doprowadziła do zawieszania konfliktu ${ }^{265}$. Wojciech Górecki zwraca uwagę, że doprowadzając do przerwania walk, Rosja zyskała niekwestionowaną przez innych pośredników pozycję czołowego - i niezbędnego - mediatora w konflikcie ${ }^{266}$. Proces mediacyjny umocnił pozycję Rosji w regionie.

Piąty etap obejmował lata 2016-2020 i charakteryzował się naprzemiennym względnym wyciszaniem napięcia i jego wzrostem. Jako przykład można wskazać zbrojne starcia w 2017 r. (z 24 na 25 lutego, z 15 na 17 maja na 16-17 Czerwiec, 4 i 7 lipca i 19

\footnotetext{
Kaukazie Południowym i zapewnieniu stworzenia stabilności i bezpieczeństwa w regionie poprzez polityczne uregulowanie konfliktu karabaskiego na podstawie zasad i norm prawa międzynarodowego. Potwierdzono także znaczenie roli Grupy Mińskiej OBWE w procesie pokojowym, zob. В.А. Захаров, А.Г. Арешев, Майендорфская Декларачия 2 ноября 2008 года и ситуачия вокруг Нагорного Карабаха. Сборник статей. Москва 2009, s. 12-13.

263 Zob. Баку ответил на критику из-за помилования офичера-убийцы, https://www.bbc.com/russian/international/2012/08/120831_hungary_azerbaijan_case (4.05.2021). Достояние республики. Азербайджанского "убийчу стопором" превратили вгероя, https://lenta.ru/articles/2012/09/03/hero/ (4.05.2021).

${ }^{264}$ W. Górecki, Kaukaski węzeł..., s. 61.

265 Zob. A. Jarosiewicz, M. Falkowski, Wojna czterodniowa w Górskim Karabachu, „Analizy OSW” 2016-0406 ,

https:/www.osw.waw.pl/pl/publikacje/analizy/2016-04-06/wojna-czterodniowa-w-gorskim-karabachu (4.05.2021).

${ }^{266}$ W. Górecki, Kaukaski węzeł..., s. 62.
} 
października ${ }^{267}$. Skutkiem rosnącego napięcia były wydarzenia z lipca 2020 r., które jak się okazało było wstępem do podjęcia działań wojennych ${ }^{268}$.

\section{Rok 2020. Nowy „gorący” etap konfliktu}

\section{Preludium}

Dokonując analizy najnowszego „gorącego" etapu sporu pomiędzy Armenią a Azerbejdżanem warto bliżej przyjrzeć się sytuacji jaka miała miejsce w lipcu 2020 r. ${ }^{269}$ Wydaje się bowiem, że właśnie wydarzenia zapoczątkowane 12 lipca tegoż roku, tj. ostre starcia pomiędzy siłami zbrojnymi tych państw, stały się katalizatorem późniejszej wojny. Krzysztof Strachota, analityk Ośrodka Studiów Wschodnich, zwraca uwagę na fakt, że chociaż obie strony obarczały się odpowiedzialnością za wybuch konfliktu (co akcentowała strona ormiańska) i eskalację walk (co podkreślał Azerbejdżan), czas i miejsce starć były z powodów politycznych zdecydowanie bardziej korzystne dla Armenii. Wskazuje on przy tym, że walki wybuchły poza Karabachem, co pozwalało przedstawiać działania Azerbejdżanu jako bezpośrednią agresję na Armenię, a tym samym odwoływać się do Organizacji Układu o Bezpieczeństwie Zbiorowym ${ }^{270}$. Wzrost napięcia wyzwał zaniepokojenie „społeczności międzynarodowej”. Rosja, Stany Zjednoczone, jak również Unia Europejska wezwały obie strony konfliktu do wstrzymania walk ${ }^{271}$.

267 Zob. С. Маркедонов, Нагорный Карабах - 2018: война, мир или балансирование на грани?, Аналитические статьи, Российский совет по международным делам, https://russiancouncil.ru/analytics-andcomments/analytics/nagornyy-karabakh-2018-voyna-mir-ili-balansirovanie-na-grani/ (4.05.2021).

268 Warto wskazać, iż w maju 2018 r. w wyniku aksamitnej rewolucji władzę w Armenii przejął Nikol Paszynian, który uznał za swój priorytet uregulowanie konfliktu o Górski Karabach. Arkadiusz Legieć zwraca uwagę, że Paszynian został pierwszym od 1998 r. premierem Armenii spoza tzw. klanu karabaskiego (grupa polityków, oligarchów i wojskowych wywodząca się z GK, opowiadająca się za twardą polityką wobec Azerbejdżanu), co dawało szanse na przełom w negocjacjach z Azerbejdżanem, zob. A. Legieć Perspektywy rozwiąania konfliktu o Górski Karabach, Biuletyn PISM, 2019-11-29, nr $168 \quad$ (1963), https://pism.pl/publikacje/Perspektywy_rozwiazania_konfliktu_o_Gorski_Karabach_(4.05.2021).

${ }^{269}$ Warto w tym miejscu odnotować, iż wpływ na rosnące napięcie pomiędzy Armenią, Republice Górskiego Karabachu a Azerbejdżanem miały m.in. czynniki wewnętrzne w obu państwach i RBK, które sprzyjały radykalizacji nastrojów, zob. Koniec status quo? Azerska rekonkwista Górskiego Karabachu, Ośrodek Studiów Przestrzeni Postsowieckiej, Analiza OSPP 48, 07.10.2020, https://www.wojskopolskie.pl/aszwoj/u/9f/68/9f68ba0b-907e-4b3c-ad30-ed8ae23448d6/analiza_ospp_pazdziernik_2020_-

_koniec_status_quo_azerska_rekonkwista_gorskiego_karabachu.pdf (6.05.2021).

270 Zob. K. Strachota, Ostre walki między Armeniq i Azerbejdżanem, „Analizy OSW” 2020-07-16, https://www.osw.waw.pl/pl/publikacje/analizy/2020-07-16/ostre-walki-miedzy-armenia-i-azerbejdzanem (06.05.2020).

271 Zob. K. Gadera, Kaukaz na skraju wojny. Starcia armeńsko-azerbejdżánskie wlipcu 2020, https:/www.konflikty.pl/historia/czasy-najnowsze/kaukaz-na-skraju-wojny-starcia-armensko-azerbejdzanskie2020/ (06.05.2021). 
W kontekście wybuchu wojny 44-dniowej warto również zwrócić uwagę na informację z października 2020 r., głoszącą, że za rozpoczęciem wojny stała Turcja, która ją zaplanowała i sprowokowała. Miały o tym świadczyć wspólne ćwiczenia tureckiej i azerbejdżańskiej armii przeprowadzone w sierpniu 2020 r., po których wojskowi tureccy mieli pozostać w Azerbejdżanie ${ }^{272}$. Ciężko jest wskazać czy informacje te były wiarygodne, a jeśli tak, to na ile. Niezależnie od tego, sam fakt, że pojawiły się one w renomowanym rosyjskim dzienniku, jakim jest „Kommersant” wskazuje, iż nie można takiego scenariusza wykluczać. Oczywiście trzeba mieć na uwadze, że równolegle do działań wojennych były prowadzone bardzo intensywne działania informacyjne i dezinformacyjne, nie tylko po stronie Armenii, Azerbejdżanu, ale również Turcji i Rosji. Rosji, która ewidentnie, także w wymiarze informacyjnym, próbowała przesunąć ciężar odpowiedzialności za wywołanie tej wojny na Turcję (była pośrednio stroną w konflikcie), co w przyszłości utrudniałoby jej prowadzenie mediacji.

\section{Wybuch i przebieg dzialań wojennych}

Działania wojenne rozpoczęły się 27 września 2020 r. i toczyły się na całej linii kontaktowej, rozdzielającej obszary kontrolowane przez Azerbejdżan od separatystycznej Republiki Górskiego Karabachu. Ofensywa wojsk azerbejdżańskich w pierwszych dniach przyniosła sukces w postaci zdobycia kilku wiosek niedaleko od miasta Füzuli oraz szczytu w paśmie górskim Murowdag ${ }^{273}$. Następnie dało się zauważyć spowolnienie natarcia, które ograniczyło się głównie do ostrzału artyleryjskiego oraz rakietowego przy dużym udziale

\footnotetext{
272 Według danych miało być to 600 żołnierzy, w tym dwustuosobowa batalionowa grupa taktyczna, 50 instruktorów w regionie Nachiczewanu, 90 doradców wojskowych w Baku zajmujących się zabezpieczeniem łączności między brygadą, korpusem i sztabem generalnym, 120 technicznych specjalistów w bazie w Qəbələ, 20 operatorów dronów w bazie lotniczej w Dəllər, 50 specjalistów na lotnisku w mieście Yevlax, 50 instruktorów w czwartym korpusie armii w Pirəkəşkül oraz 20 żołnierzy w bazie wojenno-morskiej i Akademii Wojskowej im. Heydara Đliyeva w Baku. Ponadto w Azerbejdżanie również znajdowało się rzekomo 18 bojowych wozów piechoty, jedna wieloprowadnicowa wyrzutnia rakietowa, 10 pojazdów i do 34 samolotów (w tym 6 samolotów, 8 śmigłowców, do 20 dronów), które zapewniały wywiad wojskowy zarówno w regionie Karabachu, jak i w Armenii, zob. Е. Черненко, Принуждение к конфликту. Источники " $\mathrm{b}$ ” рассказали, как Турчия готовила почву для обострения в Нагорном Карабахе, https://www.kommersant.ru/doc/4537733 (06.05.2021).

273 Zob. И. Дунаевский, Война без победы, https://rg.ru/2020/09/28/situaciia-v-nagornom-karabaheprodolzhaet-uhudshatsia.html (07.05.2021). W. Górecki, Nowa odstona konfliktu o Górski Karabach, „Analizy OSW" 2020-09-28, https://www.osw.waw.pl/pl/publikacje/analizy/2020-09-28/nowa-odslona-konfliktu-ogorski-karabach (07.05.2021). Карабах: хроника войны-2020, https://www.kavkaz-uzel.eu/articles/354861/ (07.05.2021).
} 
lotnictwa i z szerokim wykorzystaniem dronów ${ }^{274}$. 1 października 2020 r. prezydenci Rosji, Stanów Zjednoczonych i Francji wydali wspólne oświadczenie w sprawie Karabachu. Przywódcy potępili eskalację przemocy w regionie, złożyli kondolencje rodzinom ofiar i wezwali strony konfliktu do natychmiastowego zakończenia działań wojennych ${ }^{275}$. Kolejne dni przyniosły nową odsłonę walk - wojna pozycyjna przerodziła się w ofensywę wojsk azerbejdżańskich, rozpoczynając kolejną operację lądową, w wyniku której przejęto kontrolę nad kilkoma miejscowościami ${ }^{276}$. Siły azerbejdżańskie nadal ostrzeliwały cele w Górskim Karabachu, w tym jego stolicę Stepanakert. Natomiast siły ormiańskie dokonały ostrzału miast leżących w Azerbejdżanie, m.in. Gandży ${ }^{277}$. Przedłużający się konflikt budził coraz większe zaniepokojenie społeczności międzynarodowej, w tym Rosji, która zdecydowała się na podjęcie działań rozjemczych pomiędzy Armenią a Azerbejdżanem. 8 października prezydent Rosji Władimir Putin zaproponował zawieszenie broni, którego celem miała być wymiana więźniów i ciał zmarłych, a także zaprosił na 9 października do Moskwy ministrów spraw zagranicznych Azerbejdżanu i Armenii na konsultacje, które miałyby odbyć się przy pośrednictwie rosyjskiego ministra spraw zagranicznych ${ }^{278}$. Po dziesięciogodzinnych negocjacjach, nocą z 9 na 10 października minister spraw zagranicznych Rosji Siergiej Ławrow ogłosił, że strony osiągnęły porozumienie w sprawie zawieszenia walk, które miało nastąpić 10 października o godzinie 12:00. Obejmowało ono cztery punkty: 1) wymianę jeńców wojennych i innych zatrzymanych oraz ciał zmarłych zgodnie z kryteriami Międzynarodowego Czerwonego Krzyża; 2) szczegóły zawieszenia broni miały zostać dodatkowo uzgodnione; 3) Armenia i Azerbejdżan, przy pośrednictwie

\footnotetext{
${ }^{274}$ Zob. W. Górecki (współpraca: Katarzyna Chawryło, Mateusz Chudziak), Górski Karabach: poczatek wojny pozycyjnej, „Analizy OSW” 2020-09-30, https://www.osw.waw.pl/pl/publikacje/analizy/2020-09-30/gorskikarabach-poczatek-wojny-pozycyjnej (07.05.2021). Бои в Карабахе. Сводка за 1 октября, https://www.kommersant.ru/doc/4512629 (07.05.2021). Бои в Карабахе. Сводка $3 а .2$ октября https://www.kommersant.ru/doc/4518779 (07.05.2021).

${ }^{275}$ Zob. Путин, Трамп и Макрон согласовали заявление по ситуачии в Нагорном Карабахе, https://iz.ru/1068016/2020-10-01/putin-tramp-i-makron-soglasovali-zaiavlenie-po-situatcii-v-nagornomkarabakhe (07.05.2021).

${ }^{276}$ W. Górecki wskazywał, że wśród tych miejscowości były te położone prawdopodobnie nad Madagizem na północnym wschodzie i Dżebraiłem na południowym wschodzie rejonu konfliktu. Strona ormiańska tym stratom - potwierdzonym przez prezydenta Azerbejdżanu Ilhama Alijewa - zaprzeczała, zob. W. Górecki, Wojna w Górskim Karabachu: wzrost przewagi Azerbejdżanu, „Analizy OSW” 2020-10-05, https://www.osw.waw.pl/pl/publikacje/analizy/2020-10-05/wojna-w-gorskim-karabachu-wzrost-przewagiazerbejdzanu (07.05.2021).

277 W. Górecki, Wojna w Górskim Karabachu: wzrost przewagi... Бои в Карабахе. Сводка за 3 октября, https://www.kommersant.ru/doc/4519221 (07.05.2021). Бои в Карабахе. Сводка за 4 октября, https://www.kommersant.ru/doc/4519416 (07.05.2021).

278 Zob. Путин пригласил глав МИДов Азербайджана и Армении на переговоры в Москву, https://www.kommersant.ru/doc/4522178\#id1962787 (07.05.2021).
} 
współprzewodniczących Mińskiej Grupy OBWE, rozpoczęły merytoryczne negocjacje w celu jak najszybszego pokojowego uregulowania sporu; 4) strony potwierdziły niezmienność formatu procesu negocjacyjnego ${ }^{279}$. Jak szybko się okazało, rozejm nie był przestrzegany, a strony wzajemnie się oskarżały o jego łamanie i prowokacje ${ }^{280}$. Z uwagi na ponownie zaostrzającą się sytuację, m.in. władze Armenii informowały o ostrzale przez siły azerbejdżańskie Stepanakertu, Szuszy i 120 innych osad w Górskim Karabachu ${ }^{281}$. Rosyjski minister spraw zagranicznych Sergiej Ławrow powiedział, że siły pokojowe powinny zostać rozmieszczone w strefie konfliktu w Górskim Karabachu. Zaznaczył także, że Moskwa uważa, że w regionie powinni być obecni rosyjscy obserwatorzy, zwracając jednocześnie uwagę, że ostatnie słowo należy do stron konfliktu. Ponadto, rosyjski minister obrony Siergiej Szojgu poinformował, że powiadomił Azerbejdżan i Armenię o konieczności spotkań również przy udziale resortów obrony w celu wypracowania mechanizmów weryfikacji rozejmu ${ }^{282}$. W związku z dalszym nieprzestrzeganiem zawartego porozumienia ${ }^{283}$, Moskwa podjęła się kolejnej próby rozmów z Armenią i Azerbejdżanem i 17 października po konsultacjach telefonicznych ministrów spraw zagranicznych Rosji, Armenii i Azerbejdżanu uzgodniono zawieszenie broni, które miało zacząć obowiązywać od godziny 00:00 18 października ${ }^{284}$. Podobnie jak miało to miejsce $\mathrm{w}$ przypadku zawieszenia broni $\mathrm{z}$ dnia 10 października, to porozumienie również długo nie przetrwało. Już 19 października media donosiły o intensywnych walkach w kelbadżarskim rejonie, w którym siły azerbejdżańskie zdobyły 13 wsi $^{285}$. Warto również odnotować wywiad, którego dla „Kommersanta” udzielił prezydent Armenii Armen Sarkissian, gdzie powiedział, że Erywań uzna niepodległość

\footnotetext{
279 Zob. П. Тарасенко, Нагорный Карабах дождался перемирия, https://www.kommersant.ru/doc/4528751\#id1962787 (07.05.2021).

${ }^{280}$ Zob. Лавров заявил о неполном соблюдении режима прекращения огня в Карабахе, https://iz.ru/1072648/2020-10-12/lavrov-zaiavil-o-nepolnom-sobliudenii-rezhima-prekrashcheniia-ognia-vkarabakhe (07.05.2021). Бои в Карабахе. Сводка за 11 октября, https://www.kommersant.ru/doc/4528995 (07.05.2021). K. Chawryło, W. Górecki, Górski Karabach: kruchy rozejm, Analizy 2020-10-12, https://www.osw.waw.pl/pl/publikacje/analizy/2020-10-12/gorski-karabach-kruchy-rozejm (07.05.2021).

${ }^{281}$ Zob. Бои в Карабахе. Сводка за 12 октября, https://www.kommersant.ru/doc/4529640 (07.05.2021). Бои в Карабахе. Сводка за 13 октября, https://www.kommersant.ru/doc/4530289 (08.05.2021).
}

282 Zob. Лавров заявил о необходимости присутствия миротвориев в Карабахе, https://www.gazeta.ru/politics/news/2020/10/14/n_15078739.shtml (08.05.2021).

${ }^{283}$ Zob. Бои в Карабахе. Сводка за 14 октября, https://www.kommersant.ru/doc/4530985 (08.05.2021). Бои в Карабахе. Сводка за 15 октября, https://www.kommersant.ru/doc/4531624 (08.05.2021). Бои в Карабахе. Сводка за 16 октября, https://www.kommersant.ru/doc/4537764 (08.05.2021).

284 Zob. Армения и Азербайджан договорились о гуманитарном перемирии в Карабахе, https://tass.ru/mezhdunarodnaya-panorama/9746921 (08.05.2021).

${ }^{285}$ Zob. Бои в Карабахе. Сводка за 19 октября, https://www.kommersant.ru/doc/4539166 (08.05.2021); 
Republiki Górskiego Karabachu, jeśli Azerbejdżan odmówi dialogu ${ }^{286}$. Kolejne dni to dalsze walki, które toczyły się m.in. wzdłuż linii kontaktowej oraz przy granicy Górskiego Karabachu z Iranem, w których znaczną przewagę osiągnął Azerbejdżan. Zdobył m.in. miasto Zangalen i kilkadziesiąt wsi i osad w rejonach fizulińskim, dżebrailskim i zangilańskim, co w rezultacie pozwoliło Azerbejdżanowi odciąć Górski Karabach od granicy z Iranem ${ }^{287}$. W międzyczasie USA zdecydowały się podjąć próby przeprowadzenia negocjacji pomiędzy walczącymi stronami, o czym 21 października 2020 r. poinformował sekretarz stanu Mike Pompeo wskazując, że 23 października 2020 r. przeprowadzi rozmowy z ministrami spraw zagranicznych Azerbejdżanu i Armenii ${ }^{288}$. Jak się później miało okazać rozmowy nie przyniosły oczekiwanych rezultatów ${ }^{289}$, o czym świadczyły toczone, choć z mniejszą intensywnością walki na różnych kierunkach w kolejnych dniach. Armenia i Azerbejdżan nawzajem obwiniały się o nieprzestrzeganie uzgodnień o zawieszeniu broni ${ }^{290}$. W kontekście inicjatyw pokojowego uregulowania konfliktu warto również odnotować propozycję Iranu, który poinformował o gotowości $\mathrm{w}$ pośredniczeniu $\mathrm{w}$ rozmowach pomiędzy walczącymi stronami ${ }^{291}$ i następnie przedstawił plan rozwiązania konfliktu przy udziale Rosji i Turcji ${ }^{292}$. Propozycja ta nie spotkała się jednak z zainteresowaniem Armenii, podkreślającej z jednej strony konstruktywną postawę Teheranu, ale wskazującej jednocześnie, że jedynym

\footnotetext{
286 Zob. «Для армянской стороны победа - это сохранить свой дом», https://www.kommersant.ru/doc/4538437 (08.05.2021).

${ }^{287}$ Zob. Бои в Карабахе. Сводка за 20 октября, https://www.kommersant.ru/doc/4539808 (08.05.2021); Бои в Карабахе. Сводка за 21 октября, https://www.kommersant.ru/doc/4540556 (08.05.2021). Бои в Карабахе. Сводка за 22 октября, https://www.kommersant.ru/doc/4541236 (08.05.2021). W. Górecki, Górski Karabach: sukcesy militarne Azerbejdżanu, „Analizy OSW” 2020-10-20, https:/www.osw.waw.pl/pl/publikacje/analizy/2020-10-20/gorski-karabach-sukcesy-militarne-azerbejdzanu (08.05.2021).

288 Zob. Помпео заявил, что проведет 23 октября переговоры с главами МИД Азербайджана и Армении, https://tass.ru/mezhdunarodnaya-panorama/9779603 (08.05.2021).

${ }^{289}$ Od 26 października walczące ze sobą strony miały zawiesić prowadzenie działań wojennych.

${ }^{290}$ Zob. Бои в Карабахе. Сводка за 24 октября, https://www.kommersant.ru/doc/4547686 (08.05.2021). Бои в Карабахе. Сводка за 25 октября, https://www.kommersant.ru/doc/4548064 (08.05.2021). Бои в Карабахе. Сводка за 26 октября, https://www.kommersant.ru/doc/4548860 (08.05.2021). Бои в Карабахе. Сводка за 27 октября, https://www.kommersant.ru/doc/4549548 (08.05.2021). Бои в Карабахе. Сводка за 28 октября, https://www.kommersant.ru/doc/4550297 (08.05.2021). W. Górecki, Górski Karabach: wojna z dyplomacja w tle, „Analizy OSW” 2020-10-29, https://www.osw.waw.pl/pl/publikacje/analizy/2020-10-29/gorski-karabachwojna-z-dyplomacja-w-tle (08.05.2021).

291 Zob. А. Поплавский, Война в Карабахе: как конфликт Еревана и Баку бьет по Тегерану, https://www.gazeta.ru/politics/2020/10/28_a_13336159.shtml (08.05.2021).

292 Zob. Иран предложил план урегулирования в Карабахе с участием России и Туриии, https://ria.ru/20201030/karabakh-1582253303.html (08.05.2021).
} 
formatem, w ramach którego konflikt może być uregulowany jest Grupa Mińska OBWE ${ }^{293}$. W kontekście toczonych walk, również na polu walki informacyjnej należy zwrócić uwagę, że Armenia wskazywała, że Turcja wysyła bojowników z Syrii i Libii do walk w Górskim $K \operatorname{arabachu}^{294}$. Do spotkania, właśnie pod egidą, Grupy Mińskiej OBWE doszło 30 października w Genewie. Ministrowie spraw zagranicznych Armenii i Azerbejdżanu uzgodnili, że strony konfliktu, zgodnie z międzynarodowym prawem humanitarnym nie będą celowo atakować obiektów cywilnych oraz samych cywili. Ponadto, strony oświadczyły, że będą aktywnie uczestniczyć w operacjach poszukiwania i wymiany ciał zabitych, zapewniając przy tym bezpieczeństwo podczas takiej pracy, a także zdecydowały o przekazaniu list jeńców wojennych do OBWE i Międzynarodowego Czerwonego Krzyża ${ }^{295}$. Wraz z początkiem listopada widać było coraz większą przewagę sił azerbejdżańskich ${ }^{296}$. Licząc od początku rozpoczęcia wojny - jak zwraca uwagę Wojciech Górecki - przejęły one kontrolę nad jedną trzecią separatystycznej Republiki Górskiego Karabachu ${ }^{297} .8$ listopada prezydent Azerbejdżanu Ilham Alijew poinformował o zdobyciu miasta Szusza ${ }^{298}$. Z kolei minister obrony Armenii Arcrun Owannisjan powiedział, że walki nadal się toczą a Szusza nie została zdobyta (choć siły azerbejdżańskie dominowały). W rzeczywistości trudno było określić pod czyją kontrolą była wówczas Szusza, ponieważ sytuacja była bardzo dynamiczna,

293 Zob. Армения отвергла посредничество Ирана и Туриии в Нагорном Карабахе, https://lenta.ru/news/2020/10/29/bez_nih/(08.05.2021).

${ }^{294}$ Zob. Бои в Карабахе. Сводка за 29 октября, https://www.kommersant.ru/doc/4551068 (08.05.2021).

295 Zob. Баку и Ереван договорились не обстреливать мирных жителей, https:/www.kavkazuzel.eu/articles/355942/ (10.05.2021). М. Коваленко, Переговорно-карабахский конфликт, https://www.kommersant.ru/doc/4556864 (10.05.2021). В Женеве завершилась встреча глав МИД Армении и Азербайджана,

https://iz.ru/1080898/2020-10-30/v-zheneve-zavershilas-vstrecha-glav-mid-armenii-i-azerbaidzhana (10.05.2021).

${ }^{296}$ Zob. Бои в Карабахе. Сводка за 1 ноября, https://www.kommersant.ru/doc/4557414 (10.05.2021). Бои в Карабахе. Сводка за 2 ноября, https://www.kommersant.ru/doc/4558128 (10.05.2021). Бои в Карабахе. Сводка за 3 ноября, https://www.kommersant.ru/doc/4558767 (10.05.2021). Бои в Карабахе. Сводка за 4 ноября, https://www.kommersant.ru/doc/4559094 (10.05.2021). Бои в Карабахе. Сводка за 5 ноября, https://www.kommersant.ru/doc/4559725 (10.05.2021). Бои в Карабахе. Сводка за 6 ноября, https://www.kommersant.ru/doc/4564266 (10.05.2021).

${ }^{297}$ Zob. W. Górecki, Górski Karabach: kluczowa faza azerbejdżańskiej ofensywy, „Analizy OSW” 2020-11-06, https://www.osw.waw.pl/pl/publikacje/analizy/2020-11-06/gorski-karabach-kluczowa-faza-azerbejdzanskiejofensywy (10.05.2021);

${ }^{298}$ Warto nadmienić, iż Szusza to jedno z kluczowych miast Górskiego Karabachu. Znajduje się zaledwie $11 \mathrm{~km}$ od stolicy Republiki Górskiego Karabachu - Stepanakertu. Miasto położone jest na wzgórzu (1368 m n.p.m), co zapewnia mu dominującą pozycję w przypadku działań wojennych. W przypadku jego zdobycia otwiera drogę do stolicy Republiki Górskiego Karabachu - Stepanakertu. 
a intensywne walki nadal wówczas się toczyły ${ }^{299}$. 9 listopada władze Republiki Górskiego Karabachu poinformowały o utracie kontroli nad Szuszą, co stało się kluczowym momentem prowadzonych walk ${ }^{300}$.

\section{Zawieszenie walk i wspólne 9 punktowe oświadczenie}

Z 9 na 10 listopada 2020 r. premier Armenii Nikol Paszynian oraz prezydenci Azerbejdżanu i Rosji Ilham Alijew i Władimir Putin podpisali 9 punktowe oświadczenie o wstrzymaniu walk w rejonie konfliktu karabaskiego. Rozejm zakładał, że walczące strony powstrzymają się od wszelkich działań wojennych w strefie konfliktu o Górski Karabach i zatrzymają się na zajmowanych przez siebie pozycjach. Punkt drugi stanowił, iż do 20 listopada 2020 r. Armenia ma przekazać Azerbejdżanowi rejon agdamski. W kolejnym punkcie była mowa, iż wzdłuż linii kontaktowej i wzdłuż korytarza laczyńskiego rozlokowany zostanie kontyngent pokojowy Federacji Rosyjskiej w liczbie 1960 żołnierzy z bronią strzelecką, 90 transporterów opancerzonych, 380 sztuk samochodów i sprzętu specjalnego. Punkt czwarty wskazywał, iż kontyngent pokojowy Federacji Rosyjskiej zostanie rozmieszczany równolegle $\mathrm{z}$ wycofaniem armeńskich sił zbrojnych, $\mathrm{z}$ określeniem 5 letniego czasu jego stacjonowania. Punkt piąty zakładał utworzenie centrum pokojowego, monitorującego zawieszenie broni, które będzie służyło zwiększeniu skuteczności sprawowania kontroli nad realizacją porozumień przez strony konfliktu. W kolejnym punkcie określono, że do 15 listopada 2020 r. Armenia zwróci Azerbejdżanowi rejon kelbadżarski, a do 1 grudnia 2020 r. rejon laczyński. Natomiast korytarz laczyński, który będzie zapewniał połączenie Górskiego Karabachu z Armenią pozostanie pod kontrolą rosyjskiego kontyngentu pokojowego. Azerbejdżan miał zagwarantować bezpieczeństwo ruchu obywateli, pojazdów i towarów w korytarzu laczyńskim w obu kierunkach. Zgodnie z siódmym punktem przesiedleńcy wewnętrzni i uchodźcy powrócą na terytorium Górskiego Karabachu i obszarów przyległych, podlegających kontroli Urzędu Wysokiego Komisarza Narodów

\footnotetext{
299 Zob. Э. Байназаров, А. Лавров, Часть Шуии: как изменит ход войны в Карабахе потеря города, https://iz.ru/1084341/elnar-bainazarov-anton-lavrov/chast-shushi-kak-izmenit-khod-voiny-v-karabakhe-poteriagoroda (10.05.2021); Бои в Карабахе. Сводка за 7 ноября, https://www.kommersant.ru/doc/4564566 (10.05.2021). Бои в Карабахе. Сводка за 8 ноября, https://www.kommersant.ru/doc/4564769 (10.05.2021). W. Górecki, Górski Karabach: Azerbejdżan na drodze do zwycięstwa, „Analizy OSW” 2020-11-09, https://www.osw.waw.pl/pl/publikacje/analizy/2020-11-09/gorski-karabach-azerbejdzan-na-drodze-dozwyciestwa (10.05.2021).

300 Zob. Власти Нагорного Карабаха признали утрату контроля над Шуши, https://www.kavkazuzel.eu/articles/356278/ (12.05.2021).
} 
Zjednoczonych ds. Uchodźców. Punkt ósmy zakładał wymianę jeńców wojennych, zakładników i innych zatrzymanych osób oraz ciał zmarłych. Natomiast w ostatnim punkcie była mowa, iż wszystkie połączenia gospodarcze i transportowe $\mathrm{w}$ regionie mają zostać odblokowane. Armenia miała zagwarantować bezpieczeństwo połączeń transportowych między zachodnimi regionami Azerbejdżanu i Autonomiczną Republiką Nachiczewanu. Natomiast kontrolę komunikacji transportowej miały sprawować organy rosyjskiej Służby Granicznej FSB. Ponadto punkt ten przewidywał, iż za zgodą Stron zapewniona zostanie budowa nowej komunikacji transportowej łączącej Autonomiczną Republikę Nachiczewanu z zachodnimi regionami Azerbejdżanu ${ }^{301}$.

Porozumienie było sukcesem Azerbejdżanu i pośrednio Turcji, a porażką Armenii, co było widać już po pierwszych reakcjach tych państw. Minister spraw zagranicznych Turcji Mevlut Cavusoglu na Twitterze pogratulował Azerbejdżanowi zwycięstwa na polu bitwy i przy stole negocjacyjnym ${ }^{302}$. Prezydent Azerbejdżanu Ilham Alijew wygłosił przemówienie do narodu. Powiedział, że siłami pokojowymi będą nie tylko Rosjanie, ale także Turcy ${ }^{303}$. Natomiast podpisany dokument nazwał kapitulacją wroga ${ }^{304}$. Ministerstwo Obrony i Sztab Generalny Armenii wydały wspólne oświadczenie w związku z protestami po ogłoszeniu zakończenia wojny w Karabachu. Wezwali do unikania działań, które „mogą wstrząsnąć podstawami państwowości”. Ponadto, wojsko zaoferowało, że wyciągnie wnioski ze wszystkich możliwych błędów i stworzy „nieporównywalnie silniejszą i wydajniejszą armię”. Z kolei prezydent Armenii Armen Sarkissian powiedział, że dowiedział się o trójstronnym oświadczeniu w sprawie Karabachu z prasy i nie brał udziału w żadnych dyskusjach ${ }^{305}$.

W kontekście zawarcia porozumienia i tym samym zakończenia walk warto nadmienić, że podobnie jak wojna z lat 1992-1994, również wojna 44-dniowa spowodowała, że dziesiątki tysięcy mieszkańców Górskiego Karabachu i rejonów do niego przyległych

\footnotetext{
301 Zob. Заявление Президента Азербайджанской Республики, Премьер-министра Республики Армения и Президента Российской Федерачии, http://kremlin.ru/events/president/news/64384 (12.05.2021).

302 Zob. Глава МИД Турчии поздравил Баку с «важной победой», https://www.rbc.ru/politics/10/11/2020/5faa30dc9a79473e227c1aee (12.05.2021).

${ }^{303}$ Należy nadmienić, iż w opublikowanym dokumencie nie ma wzmianki o Turcji. Rosyjskie MSZ i rzecznik prezydenta Putina, Dmitrij Pieskow zdementowali to. Dodatkowo, Pieskow wskazał, że Turcja może pomóc Azerbejdżanowi w utworzeniu centrum monitorowania warunków zawieszenia broni. Centrum jednak będzie zlokalizowane na terytorium samego Azerbejdżanu, poza Karabachem, zob. А. Голубева, Г. Атанесян, В. Дергачев, П. Козлов, Семь вопросов к миру в Карабахе. Кто от этого выиграл и что будет дальше? https://www.bbc.com/russian/features-54896303 (12.05.2021).

304 Zob. Алиев счел соглашение по Карабаху капитуляцией Армении, https://www.rbc.ru/politics/10/11/2020/5fa9d8bc9a79471d5963b1e4 (12.05.2021).

305 Zob. Армения заключила мир и пошла на уступки Азербайджану, https://www.rbc.ru/politics/10/11/2020/5fa9b4249a794714efa5ea83 (12.05.2021).
} 
zmuszonych było do ucieczki ${ }^{306}$. W samej wojnie zginęło kilka tysięcy osób ${ }^{307}$ i zostało zniszczonych wiele domów mieszkalnych, obiektów użyteczności publicznej i infrastruktury ${ }^{308}$.

\section{Postawa Rosji}

Federacja Rosyjska wraz ze Stanami Zjednoczonymi oraz Francją od 1992 roku współprzewodniczy Grupie Mińskiej OBWE i od początku lat 90. XX w. odgrywa na Kaukazie istotną rolę w mediacjach między Armenią i Azerbejdżanem w sporze o Górski Karabach $^{309}$. Rosja dzięki wykorzystaniu swoich przewag w walce informacyjnej oraz dzięki powściągliwej postawie $\mathrm{w}$ odniesieniu do najnowszej odsłony konfliktu potrafiła spowodować powstrzymanie działań wojennych i doprowadziła do wprowadzenia swoich wojsk do Górskiego Karabachu, umacniając tym samym swoją pozycję w regionie ${ }^{310}$.

\footnotetext{
${ }^{306}$ Georgij Bondariew przytacza dane rządu Armenii (stan na początek listopada 2020 r.), które wskazywały, że ok. 90000 osób opuściło Górski Karabach udając się albo do Armenii albo do bezpieczniejszych rejonów Górskiego Karabachu. Według danych armeńskiego Ministerstwa Pracy i Spraw Socjalnych do Armenii przybyło ok. 40000 osób z Górskiego Karabachu, zob. Г. Бондарев, Ереван оставил Карабах с демографическими проблемами, https://www.ng.ru/cis/2020-11-13/100_131120.html (20.05.2021). Z kolei według danych, które zostały przekazane 23 lutego 2021 r. przez rosyjskie siły pokojowe, 52681 osób wróciło na terytorium Górskiego Karabachu, zob. М. Фалалеев, Дорога домой, В Нагорный Карабах вернулось свыме 50 тысяч беженцев, https://rg.ru/2021/02/23/v-nagornyj-karabah-vernulos-svyshe-50-tysiachbezhencev.html (20.05.2021).

${ }^{307} \mathrm{~W}$ przestrzeni medialnej pojawia się szereg informacji na temat liczby osób, które poniosły śmierć w wyniku wojny. Za Jurijem Wendikiem, który kilka dni po zakończeniu walk szacował straty można przytoczyć następujące dane: Ministerstwo Obrony Armenii i Górskiego Karabachu podało liczbę 1383 Ormian, którzy zginęli, wskazując jednocześnie, że dane te mogą być niepełne; z kolei Ministerstwo Ochrony Zdrowia Armenii odnotowało liczbę 2317 żołnierzy, którzy zginęli. Natomiast były ambasador Armenii wskazywał na liczbę 4750 Ormian (3750 - zginęło, 1100 - nie wiadomo co się z nimi stało). Według prezydenta Rosji łączna liczba osób (Ormianie i Azerbejdżanie), które zginęły w wojnie to ponad 4000, a rannych zostało ponad 8000, zob. Ю. Вендик Армения начинает считать погибших в Карабахе. В Ереване прошел многотысячный мари памяти, https://www.bbc.com/russian/news-54943958 (20.05.2021). Według Ministerstwa Obrony Azerbejdżanu (dane z początku grudnia 2020) liczba żołnierzy, którzy zginęli wyniosła 2783, ponad 100 zaginęło a 1245 przebywało w szpitalach. Ministerstwo Zdrowia Armenii wskazało, że liczba Ormian, którzy zginęli wyniosła 2718, zob. Азербайджан впервые раскрыл потери в войне в Карабахе, https://www.bbc.com/russian/news-55149056 (20.05.2021).
}

308 Zob. В ООН подняли вопрос разрушенной инфраструктуры в Карабахе, https://az.sputniknews.ru/karabakh/20210429/426824012/un-karabakh-azerbaijan-war.html (20.05.2021).

${ }^{309}$ Grupa Mińska została utworzona w 1992 r., w jej skład oprócz państw współprzewodniczących Grupie i stron konfliktu wchodzą również: Białoruś, Niemcy, Włochy, Portugalia, Holandia, Szwecja oraz Finlandia.

310 Pax Russo-Turcica. Stosunki rosyjsko-tureckie po wojnie o Górski Karabach, Centrum Badań nad Bezpieczeństwem Akademii Sztuki Wojennej, Raport OSPP, Warszawa 2021, https://www.wojskopolskie.pl/aszwoj/u/84/49/84491f38-f859-45f1-9a6f-

84b65011aa92/ospp_raport_marzec_2021_pax_russo_turcica_stosunki_rosyjsko_tureckie_po_wojnie_o_gorski_ karabach.pdf(20.05.2021), s. 11. 
Świadczy to o pewnej ewolucji w zastosowaniu rosyjskiej sztuki operacyjnej ${ }^{311}$. W przypadku jesiennej wojny karabaskiej, Moskwa zdecydowała się na zastosowanie wariantu „utrzymania pokoju" (peacekeeping) z wachlarza charakterystycznego dla misji i operacji pokojowych, w odróżnieniu od operacji „wymuszenia pokoju” (peace enforcement) podczas wojny w Gruzji w $2008 \mathrm{r}^{312}$. Dlatego też, obecność komponentu wojskowego w Górskim Karabachu ma charakter następczy ${ }^{313}$. Pojawia się on w rezultacie porozumienia osiągniętego przez strony konfliktu. Do tego czasu Rosja w sporze pełniła jedynie rolę mediatora. W omawianym przypadku nie ma mowy o prewencyjnym wykorzystaniu wojsk. Cele Kremla zostały osiągnięte $\mathrm{w}$ wyniku umiejętnie prowadzonych negocjacji, dzięki odpowiedniej grze dyplomatycznej z Baku, Erywaniem oraz Ankarą ${ }^{314}$.

Dziennikarze BBC zwracają uwagę na fakt, że formalnie Rosja nie miała podstaw do zaangażowania się w konflikt, ponieważ walki toczyły się na uznanym międzynarodowo terytorium Azerbejdżanu i nie przenosiły się na terytorium Armenii - państwa członkowskiego Organizacji Układu o Bezpieczeństwie Zbiorowym (OUBZ). Natomiast wprowadzenie sił pokojowych, zgodnie $\mathrm{z}$ prawem międzynarodowym, wiązało się z uzyskaniem zgody wojujących stron, o czym wielokrotnie wspominał rzecznik Kremla Dmitrij Pieskow. Podobnie argumentem przeciw początkowemu zaangażowaniu się w spór Rosji mogła być poważna rola Turcji, która w konflikcie opowiedziała się po stronie Baku.

\footnotetext{
${ }^{311}$ Niektórzy eksperci identyfikują zmianę postrzegania przez Rosję operacji poprzez mocniejsze rozłożenie akcentów na wspieranie zamierzeń politycznych, które z kolei bezpośrednio wpływają na cel militarny, formę i przyjęte metody działań, zob. M. Depczyński, L. Elak, Rosyjska sztuka operacyjna w zarysie, Warszawa 2020, s. 395 .

312 Moskwa tłumaczyła ówczesną agresję na Gruzję prowadzeniem operacji „wymuszania pokoju” z terytorium Osetii Południowej, zob. A. Legucka, Operacja pokojowa Rosji w Górskim Karabachu - cele i wyzwania, „Biuletyn PISM” 2021-01-29, $\quad$ nr 17 ; https://pism.pl/publikacje/Operacja_pokojowa_Rosji_w_Gorskim_Karabachu_cele_i_wyzwania (21.05.2021). ${ }^{313}$ Zob. Armenia i Azerbejdżan zgodzity się na obecność rosyjskich sit pokojowych w Górskim Karabachu, https://www.pap.pl/aktualnosci/news, 753707,armenia-i-azerbejdzan-zgodzily-sie-na-obecnosc-rosyjskich-silpokojowych-w

314 Jak sugeruje redaktor naczelny czasopisma "Россия в глобальной политике" Fiodor Łukianow, „Kreml od samego początku zajmował się konfliktem Rosja negocjowała z Turcją, kontaktowała się z Azerbejdżanem i nieformalnie udzielała wsparcia wojskowego Erewanowi”, cyt. za: А. Голубева, Г. Атанесян, В. Дергачев, П. Козлов, op. cit. Szerzej na temat „rosyjskiej szkoły negocjacyjnej” zob. S. Bieleń, Negocjacje w stosunkach międzynarodowych, Warszawa 2013, s. 298-311. Również Witold Jurasz, były dyplomata, wskazuje, że trudna sytuacja Kremla była tylko iluzją. Moskwa nie mogła porzucić swojego sojusznika - Armenii, ale nie mogła też ostatecznie zaryzykować zaostrzenia kursu wobec Baku. Kreml bowiem - według publicysty - rozumiał, że może „zdradzić” Armenię, ale powinien poczekać do momentu, gdy jedyną alternatywą dla przyjęcia upokarzających warunków zawieszenia broni będzie klęska, zob. W. Jurasz, Z małej wojny na dalekim Kaukazie wyplywaja ważne wnioski dla Polski, https://wiadomosci.onet.pl/swiat/walki-w-gorskim-karabachu-juraszwazne-wnioski-dla-polski/kj9shje (20.05.2021 r.).
} 
Wsparcie militarne Armenii mogłoby z kolei przełożyć się na rosyjsko-turecką kooperację w Syrii i Libii ${ }^{315}$.

Według części analityków to właśnie Rosja najwięcej zyskała w związku z ostatnią odsłoną konfliktu w Górskim Karabachu ${ }^{316}$. Moskwa może aktualnie wywierać naciski na państwa Kaukazu, biorąc pod uwagę jej obecność militarną w poszczególnych państwach (Armenia, Azerbejdżan, Gruzja) ${ }^{317}$. Można mówić również o zmianie status quo w regionie, biorąc pod uwagę zaangażowanie Turcji. Mimo to, dyplomacja rosyjska doprowadzając do podpisania porozumienia z 9/10 listopada 2020 r. osiągnęła sukces, choć nie brakuje krytycznych głosów wobec postępowania Moskwy ${ }^{318}$. Putin bowiem zgodził się oddać Azerbejdżanowi 7 rejonów wokół Górskiego Karabachu zajętych przez Ormian, osłabiając pozycję Armenii.

\section{Rosyjskie sily pokojowe - konsekwencje z tym związane dla regionu}

Przede wszystkim należy postawić sobie pytanie czy rosyjski kontyngent w Górskim Karabachu realizuje misję lub operację pokojową, i czym są tzw. siły pokojowe. Jeśli za Andrzejem Czupryńskim przyjmiemy, że jest to „kontyngent wojskowy, najczęściej międzynarodowy wydzielony do wykonania operacji pokojowych bądź operacji wsparcia pokoju, z mandatu Organizacji Narodów Zjednoczonych lub innej organizacji międzynarodowej" ${ }^{319}$, to w przypadku wojsk rosyjskich wysłanych do Karabachu nie może być mowy o wyczerpaniu przesłanek uprawniających do posługiwania się taką definicją. Stąd dla rozróżnienia, na potrzeby niniejszego artykułu, wyrażenie to jest używane zgodnie z literalnym tłumaczeniem ros. миротворческие сильл $Р \Phi^{320}$. Tak więc, rosyjskie "siły

315 Trudno byłoby mówić o współpracy w Lewancie, pośrednio występując przeciw sobie w Górskim Karabachu. Zob. А. Голубева, Г. Атанесян, В. Дергачев, П. Козлов, op. cit.

316 Zob. Stefan Meister, szef oddziału Fundacji Heinricha Bölla w Tbilisi, w rozmowie z redaktorem Wojciechem Wojtasiewiczem z „Nowej Europy Wschodniej” stwierdza, że wynegocjowane „porozumienie jest majstersztykiem Moskwy. Udało jej się osiągnąć wszystko, czego chciała od wielu lat. Wprowadziła wojska i żołnierzy na terytorium Górskiego Karabachu. W ten sposób będzie miała wpływ na Azerbejdżan, który sprawia jej pewne kłopoty i chce być niezależny. Udało jej się powstrzymać apetyt Turcji, jeśli chodzi o Kaukaz Południowy. I w jeszcze większym stopniu uzależniła od siebie Armenię.”, zob. Gdzie dwóch się bije, tam... wygrywa Rosja, „Nowa Europa Wschodnia” 2020, nr 6, s. 33.

317 Por. Legucka, op. cit.; A. Bryc, Rosja w XXI wieku. Gracz światowy czy koniec gry?, Warszawa 2009, s. $56-89$.

318 Zob. Pax Russo-Turcica..., op. cit., s. 25-26.

319 Zob. A. Czupryński, Współczesna sztuka operacyjna, Akademia Obrony Narodowej, Warszawa 2009, s. 240250.

320 Według definicji zamieszczonej na stronie internetowej Ministerstwa Obrony Cywilnej, Sytuacji Nadzwyczajnych oraz Likwidacji Następstw Klęsk Żywiołowych FR jest to „specjalny kontyngent wojskowy wchodzący w skład Sił Zbrojnych FR, utworzony 3 maja 1996 r. w celu udziału w działaniach na rzecz 
pokojowe" nie posiadają cech kontyngentu międzynarodowego, ani nie zostały wyekspediowane pod auspicjami żadnej organizacji międzynarodowej, jak np. ONZ, OBWE czy OUBZ. Mimo, że używają podobnej kolorystyki co niebieskie berety Narodów Zjednoczonych, posiadają zupełnie inny mandat i nie cieszą się taką estymą. Co znamienne, stacjonują przeważnie w przestrzeni poradzieckiej pod fasadą realizacji interesów zgodnych z oczekiwaniami „społeczności międzynarodowej” (np. zaprzestanie walk, kontrola realizacji porozumień, rozejmów, ustaleń pokojowych itp.) nieformalnie zabezpieczając partykularne interesy Moskwy.

Właściwy kontyngent wojskowy w Górskim Karabachu liczy blisko 2 tys. członków personelu, a jego trzon stanowią oddziały 15. Samodzielnej Brygady Zmechanizowanej (Pokojowej) z Centralnego Okręgu Wojskowego FR (ros. 15-я отдельная мотострелковая Александрийская бригада «миротворческая»)" 221 . Początkowo, 11 listopada 2020 r., w Karabachu pojawiły się pierwsze siły rozjemcze w liczbie ok. 400 rosyjskich żołnierzy piechoty przerzuconych przez samoloty Ił-76 na linię rozgraniczającą wojska Armenii i Azerbejdżanu. Obecnie kontyngent składa się 1960 członków personelu wojskowego z Rosji, 90 transporterów opancerzonych, 380 sztuk sprzętu samochodowego i specjalnego ${ }^{322}$, a jego zadaniem jest rozminowywanie terenu, pomoc w powrocie uchodźców oraz monitorowanie realizacji zawieszenia broni przez strony konfliktu ${ }^{323}$. Według danych Ministerstwa Obrony FR w półrocznym okresie stacjonowania zespoły inżynierów rosyjskiego kontyngentu sił pokojowych oczyściły niewybuchy na obszarze 2121 ha, 657,3 km dróg, 1844 budynki, w tym 30 obiektów o znaczeniu społecznym, a 25613 obiektów wybuchowych zostało zneutralizowane ${ }^{324}$.

\footnotetext{
utrzymania lub przywrócenia pokoju i bezpieczeństwa międzynarodowego (Jugosławia, Naddniestrze, Osetia Południowa, Abchazja, Tadżykistan i in.)", zob. Термины МЧС России, https://www.mchs.gov.ru/ministerstvo/o-ministerstve/terminy-mchs-rossii/term/2704 (20.05.2021).

321 Zob. Cztery samoloty $z$ "mirotworcami" ladowaty $w$ Armenii, https://defence24.pl/cztery-samoloty-zmirotworcami-ladowaly-w-armenii (20.05.2021 r.).

322 Za: Oficjalna strona rosyjskiego kontyngentu w Górskim Karabachu: Российский миротворческий контингент в Нагорном Карабахе http://mil.ru/russian_peacekeeping_forces.htm; (20.05.2021 r.).W górskim Karabachu sq już rosyjskie sity pokojowe, https://www.wnp.pl/rynki-zagraniczne/w-gorskim-karabachu-sa-juzrosyjskie-sily-pokojowe,430919.html (20.05.2021).

${ }^{323}$ A. Legucka, op. cit.

${ }^{324}$ Począwszy od 23 listopada 2020 r. - stan na dzień 30 maja 2021 r., dane za: Информачионный бюллетень Министерства обороны Российской Федерачии о деятельности российского миротворческого контингента в зоне нагорно-карабахского конфликта, https://mil.ru/russian_peacekeeping_forces/news/more.htm?id=12364074@egNews (30.05.2021).
} 
W ramach misji pokojowych oprócz tradycyjnych zadań wojskowych realizuje się także zadania cywilne, które coraz częściej stanowią główną część misji ${ }^{325}$. Zapewne i na tym polu Moskwa będzie próbowała się wykazać. Warto odnotować, że Wysoka Komisarz Narodów Zjednoczonych ds. Praw Człowieka (UNHCR) Michelle Bachelet wspominała o możliwości popełnienia zbrodni wojennych w Górskim Karabachu w związku $\mathrm{z}$ „masowymi” atakami na ludność cywilną ${ }^{326}$. Szczególny status będzie miał tzw. korytarz laczyński, który pozostanie pod kontrolą rosyjskich sił pokojowych. Nie do końca jasne pozostają ustalenia, dotyczące powrotu uchodźców i przesiedleńców oraz funkcjonowanie drugiego korytarza łączącego zasadniczą część Azerbejdżanu z Nachiczewańską Republiką Autonomiczną przez terytorium Armenii ${ }^{327}$.

Otwartą pozostaje również kwestia podźwignięcia się w wymiarze socjalnoekonomicznym Górskiego Karabachu zniszczonego w rezultacie działań wojennych ${ }^{328}$. Niektórzy analitycy w stacjonowaniu w regionie rosyjskich „sił pokojowych” upatrują wymiernych korzyści ekonomicznych, związanych z zaopatrywaniem i obsługą wchodzących w skład kontyngentu żołnierzy ${ }^{329}$.

Warto przeanalizować również czysto teoretyczne możliwości ewentualnego użycia siły w regionie, jakie daje Moskwie obecność wojskowa w Górskim Karabachu. Franciszek Gągor i Krzysztof Paszkowski wskazują, że „obecność wojskowa” jest charakterystyczna dla tradycyjnych operacji utrzymania pokoju, w których uczestniczą lekko uzbrojone kontyngenty wojskowe, a zastosowanie siły możliwe jest w przypadku: samoobrony (zapobieganie próbom rozbrojenia personelu sił pokojowych); obrony posterunków, obozów, pomieszczeń i pojazdów sił pokojowych, czy zaatakowanych innych jednostek sił pokojowych ${ }^{330}$. Wobec faktu, że obie strony konfliktu wyraziły zgodę na rosyjską obecność

\footnotetext{
${ }^{325}$ Zob. B. Balcerowicz, Sity zbrojne w stanie pokoju, kryzysu, wojny, Warszawa 2010, s. 197.

326 Zob. UNHCR o możliwości popełnienia zbrodni wojennych w Górskim Karabachu, https://www.pap.pl/aktualnosci/news, 749128, unhchr-o-mozliwosci-popelnienia-zbrodni-wojennych-w-gorskimkarabachu.html (21.05.2021 r.).

${ }^{327}$ Zob. W. Górecki, Górski Karabach: normalizacja petna niewiadomych, „Analizy OSW”, 2020-11-26, https://www.osw.waw.pl/pl/publikacje/analizy/2020-11-26/gorski-karabach-normalizacja-pelna-niewiadomych ${ }^{328}$ С. Маркедонов, В. Каледжи, К. Хас, op. cit.

${ }^{329}$ Zob. A. A. Məzun, Economic impact of peacekeeping forces and the case of Karabakh, Topchubashov Center, https://top-center.org/en/analytics/3084/economic-impact-of-peacekeeping-forces-andthe-case-of-karabakh (21.05.2021 r.).

${ }^{330}$ Autorzy, z perspektywy możliwości użycia siły, dzielą operacje pokojowe na cztery kategorie: mediacja $i$ obserwacja; obecność wojskowa; wzmocniona obecność wojskowa; interwencja zbrojna, zob. F. Gągor, K. Paszkowski, Międzynarodowe operacje pokojowe $w$ doktrynie obronnej RP, Warszawa-Toruń 1998, za: B. Balcerowicz, Sity zbrojne w stanie pokoju, kryzysu, wojny, Warszawa 2010, s. 205-206. Szerzej: P. Żarkowski, Zasady użycia sit zbrojnych $w$ operacjach pokojowych, „Doctrina. Studia społeczno-polityczne” 2015, nr. 12;
} 
wojskową w Górskim Karabachu zachodzi znikome prawdopodobieństwo użycia siły przez odziały mirotworców ${ }^{331}$. Natomiast nie można wykluczyć, że Moskwa zechce użyć karabaskich „sił pokojowych” w przyszłości, w sytuacji, gdy zaistnieje potrzeba „wymuszenia pokoju".

Analizując zagadnienie obecności rosyjskich mirotworców w Górskim Karabachu warto przywołać, zbieżne co do ogółu spostrzeżeń, twierdzenia badaczy zajmujących się historyczną perspektywą rosyjskich misji pokojowych.

Agnieszka Legucka zwraca uwagę na fakt, że rosyjskie misje z reguły odbiegały od praktyki operacji pokojowych ONZ. Władze rosyjskie nie dążyły do zapewnienia wielonarodowego składu kontyngentu ani jego neutralności, angażowały też strony konfliktu ${ }^{332}$. Analityczka podkreśla, że we wszystkich postsowieckich konfliktach „siły pokojowe” Rosji wspierały interesy Moskwy kosztem państw na terytorium, których stacjonowały $^{333}$. Rosja dysponuje sporym doświadczeniem w wykorzystywaniu „sił pokojowych" do wzmacniania swojej obecności w regionie. Początkowo była zwolenniczką tworzenia mieszanych komisji kontrolnych, co oznaczało, że kontyngent składał się z Rosjan i przedstawicieli walczących stron - tak było w Osetii Południowej czy Naddniestrzu. Następnie Moskwa starała się wprowadzać do swoich misji komponent międzynarodowy, co skutkowało wysyłaniem kontyngentów, w skład których wchodzili żołnierze Wspólnoty Niepodległych Państw. Oczywiście główny trzon misji stanowili Rosjanie (Abchazja 1994 r., Tadżykistan 1997 r.). Narody Zjednoczone i OBWE do regionów, w których stacjonowały „siły pokojowe” FR wysyłały jedynie misje obserwacyjne ${ }^{334}$.

Ryszard Zięba zauważa natomiast, że Rosja już od początku lat 90 XX w. zabiegała o uzyskanie mandatu międzynarodowego oraz materialnego wsparcia dla swoich „operacji pokojowych". W niektórych przypadkach Moskwa wykorzystywała do tego kontyngenty wysyłane wspólnie z żołnierzami Wspólnoty Niepodległych Państw lub we współpracy z członkami tej organizacji. Politolog twierdzi, że Moskwa już w 1994 roku dążyła do ograniczenia roli OBWE, sprowadzając ją do funkcji kontrolnych nawet bez konieczności

\footnotetext{
https://repozytorium.uph.edu.pl/bitstream/handle/11331/1286/Zarkowski.P_Zasady_uzycia_sil_zbrojnych.pdf?se quence $=1$ (21.05.2021 r.).

${ }^{331}$ Ros. мupomвopey (mirotworiec) - ten, kto godzi zwaśnionych, walczących, przyczynia się do zakończenia wojny, konfliktu. za: Словарь русского языка: В 4-х т. / РАН, Институт лингвистических исследований; Под ред. А.П. Евгеньевой. - 4-е изд., стер. - Москва: Рус. яз.; Полиграфресурсы, 1999.

${ }^{332}$ A. Legucka, op.cit.

${ }^{333}$ Pax Russo-Turcica... op. cit., s. 32.

${ }^{334}$ Zob. A. Legucka, op.cit. Por. Д. Данилов, Россия в Закавказье: в поисках мюуународной легитимачии // Б. Коппитерс (ред.), Спорные границы на Кавказе, Брюссель 1996, http://poli.vub.ac.be/publi/ContBorders/rus (21.05.2021).
} 
wymogu obecności jej obserwatorów na miejscu konfliktu. Co w praktyce oznaczać miało pozbawienie nadzoru nad prowadzonymi przez WNP operacjami, a przez to osłabienie roli OBWE jako mediatora między walczącymi stronami. W opracowaniu zaznaczono także, że chociaż niektóre państwa zachodnie wykazywały zainteresowanie rosyjską ofertą, to zważywszy na negatywne doświadczenia z poczynaniami Moskwy podczas konfliktów w Górnym Karabachu, Gruzji i Tadżykistanie, nie były jednak gotowe udzielić Rosji bezwarunkowego poparcia ${ }^{335}$.

Spostrzeżenia Ryszarda Zięby sprzed blisko ćwierćwiecza na temat ówczesnych prób uregulowania konfliktu w Górskim Karabachu, dotyczące uzasadnionych obaw co do wykorzystania przez Moskwę OBWE dla swoich działań, pozostają aktualne również w 2021 r. Rosja konsekwentnie realizuje założenia doktryny „szczególnej odpowiedzialności” za losy stabilności i pokoju na obszarze byłego ZSRR ${ }^{336}$. Nie wykorzystuje jednak oficjalnego mandatu OBWE, a jedynie swoją pozycję w regionie, wprowadzając własne „siły pokojowe”, lakonicznie posiłkując się swoją rolą w Grupy Mińskiej ${ }^{337}$. Na fakt marginalizacji tego gremium (Grupy Mińskiej) w obecnej sytuacji zwraca również uwagę Wojciech Górecki, wskazujący przede wszystkim na Moskwę i Ankarę, jako na głównych rozgrywających jesiennej wojny w Karabachu ${ }^{338}$. Kontrola międzynarodowa poczynań mirotworców pozostawia wiele do życzenia, gdyż przeważnie można mówić o jej braku lub ma ona rachityczny charakter jak np. w przypadku rosyjsko-tureckiego centrum obserwacyjnego w Górskim Karabachu ${ }^{339}$. Dlatego też najtrudniejszym momentem w relacjach między Rosją a Turcją będzie interpretacja formatu operacji pokojowej, ponieważ razem z rozmieszczeniem żołnierzy rosyjskich wzdłuż nowej linii rozgraniczenia zaproponowano utworzenie ww. centrum obserwacyjnego, które nadzorować ma wypełnienie postanowień rozejmu z udziałem przedstawicieli Ankary. Próby wtrącania się w wypełnienie gwarantującej pokój operacji i testowania pozycji Moskwy w sprawie umocnienia pozycji Turcji w regionie, wyglądają na wysoce prawdopodobne. Możliwe, że na fali sukcesu na kierunku karabaskim strona turecka

\footnotetext{
335 R. Zięba, Funkcjonowanie paneuropejskiego mechanizmu bezpieczeństwa KBWE/OBWE, „Studia Europejskie" 1998, nr 3, s. 103-104.

336 Ibidem.

${ }^{337}$ Jeszcze w październiku 2020 r. utrzymywano, że mediatorem w sporze ma być Grupa Mińska OBWE, zob. Armenia $i$ Azerbejdżan uzgodnity zawieszenie broni $w$ konflikcie o Górski Karabach, https://www.pap.pl/aktualnosci/news,733680,armenia-i-azerbejdzan-uzgodnily-zawieszenie-broni-w-konflikcieo-gorski. Natomiast dziewięciopunktowe porozumienie z listopada 2020 r. pomija tę kwestię.

${ }^{338}$ W. Górecki, Górski Karabach: kluczowa...

${ }^{339}$ Turcy wchodzq na Kaukaz. Jest porozumienie z Rosjanami, https://warsawinstitute.org/pl/turcy-wchodza-nakaukaz-jest-porozumienie-z-rosjanami/ (20.05.2021).
} 
zaktywizuje się i w innych regionach byłego ZSRR (Centralna Azja, Ukraina) ${ }^{340}$. Niektórzy eksperci prognozują, że współpraca Ankary z Rosją będzie się opierać na modelu kompartmentacji, tj. wybiórczej, sektorowej współpracy w odniesieniu do jednej dziedziny, przy kontynuacji sporu, różnic i rywalizacji w innej ${ }^{341}$.

Rekapitulując, rosyjska misja pokojowa w Górskim Karabachu może być porównywana do operacji utrzymania pokoju (peacekeeping) prowadzonych pod egidą ONZ chociaż nie jest $\mathrm{z}$ nią tożsama. Została wprowadzona na określony czas (pięć lat, z możliwością przedłużenia), po osiągnięciu zawieszenia broni i uzyskaniu akceptacji przez strony konfliktu. Jednak pozostają wątpliwości związane z jej neutralnością i brakiem międzynarodowej kontroli, np. ze strony $\mathrm{OBWE}^{342}$. Rozstrzygnięcie wojny 44-dniowej nie oznacza więc rozwiązania konfliktu karabaskiego. Jest kolejnym zamrożeniem konfliktu $\mathrm{w}$ trzydziestoletniej historii sporu. Rosja, w myśl rzymskiej zasady divide et impera, znalazła sposób na oficjalne wprowadzenie swoich wojsk do Górskiego Karabachu w charakterze „sił pokojowych", co wpisuje się w politykę Moskwy w odniesieniu do obszaru poradzieckiego i stanowi źródło nacisku w stosunku do państw, w których stacjonują tzw. rosyjskie siły pokojowe - mirotworcy, a także rozszerza obecność militarną w regionie ${ }^{343}$. Na obecność tą oprócz kontyngentu w Górskim Karabachu składają się bazy militarne i jednostki stacjonujące na terytorium państw poradzieckich (m.in. Mołdawia-Naddniestrze, Gruzja-Abchazja, Osetia Południowa) $)^{344}$. Kreml jednocześnie zyskał nowe możliwości bezpośredniego oddziaływania na dwa kaukaskie państwa Partnerstwa Wschodniego UE. Zatem, w szerszym kontekście, w każdym z państw członkowskich tego programu Europejskiej Polityki Sąsiedztwa

\footnotetext{
${ }^{340}$ C. Маркедонов, В. Каледжи, К. Хас, op. cit.

${ }^{341}$ Zob. Pax Russo-Turcica... op. cit., s. 46. Por. W. Górecki, Rywalizacja poprzez wspótpracę. Rosyjskotureckie centrum obserwacyjne na Kaukazie, ,Analizy OSW” 2021-02-02,

https://www.osw.waw.pl/pl/publikacje/analizy/2021-02-02/rywalizacja-poprzez-wspolprace-rosyjsko-tureckiecentrum-obserwacyjne (20.05.2021).

${ }^{342}$ Zob. A. Legucka, op. cit..

${ }^{343}$ Co ciekawe, rosyjscy analitycy zauważają, że sama kwestia obecności sił pokojowych w Górskim Karabachu wywołała zaniepokojenie Iranu, który pośrednio występował przeciw rozwiązaniom popieranym przez Grupę Mińską OBWE przy jednoczesnym poparciu takiego uregulowania konfliktu, w myśl którego pokój będzie zabezpieczony przez siły samych walczących stron, a także trzech sąsiednich państw - Rosji, Turcji i Iranu. Stąd pokojowa operacja pod egidą Moskwy nie powinna wywoływać zaniepokojenia Republiki Islamskiej, zob. С. Маркедонов, В. Каледжи, К. Хас, op.cit.

${ }^{344}$ Szerzej: A. Bryc, op. cit., s. 56-89. Na terytorium stron konfliktu funkcjonuje 102 rosyjska baza w Giumri (Armenia).
} 
(Armenia, Azerbejdżan, Białoruś, Gruzja, Ukraina, Mołdawia) Rosja obecna jest militarnie w mniejszym, bądź większym zakresie ${ }^{345}$.

\section{Podsumowanie}

Konflikt o Górski Karabach pomiędzy Azerbejdżanem a Armenią rozpoczął się wraz z upadkiem ZSRR, choć jego źródła sięgają początków XX w. Enklawa, zamieszkiwana w większości przez Ormian na terytorium będącym częścią Azerbejdżanu, znajdowała się pod kontrolą Armenii od czasu zwycięskiej wojny z lat początku lat 90. XX w. Przez ostatnie ponad trzydzieści lat trwania sporu można wyróżnić kilka etapów konfliktu, które cechowały się różnym stopniem intensywności walk.

Wydaje się, że zeszłoroczna jesienna eskalacja konfliktu, okazała się przełomowa nie tylko dla Armenii i Azerbejdżanu, regionu Kaukazu Południowego, ale również dla Lewantu, w którym można było zidentyfikować niecodzienną, na pierwszy rzut oka, mozaikę sojuszy. Warto obserwować rozwój sytuacji w tym zakresie, ponieważ może się okazać, że sojusze czy też współpraca nie były podejmowane w doraźnych taktycznych celach, ale kryły się za nimi strategiczne cele, które mogą skutkować większymi zmianami w wymiarze geopolitycznym.

Intensywne starcia wojsk Armenii z siłami zbrojnymi Azerbejdżanu z 2020 r. mocno angażujące inne państwa, nie tylko w wymiarze dyplomatycznym - najcięższe, i najdłużej trwające od momentu zawarcia rozejmu 26 lat wcześniej pokazały, że groźba wybuchu nowej wojny $\mathrm{w}$ dalszym ciągu pozostaje realna. W szerszym ujęciu, $\mathrm{z}$ punktu widzenia bezpieczeństwa międzynarodowego, można zaobserwować zmianę regionalnego układu sił m.in. wzrost znaczenia Turcji w regionie, o czym świadczy wsparcie militarne Turcji dla Azerbejdżanu, dystansowanie się Rosji wobec angażowania się w pomoc militarną którejś ze stron.

\section{Streszczenie:}

Niniejszy artykuł podejmuje problematykę konfliktu w Górskim Karabachu. Przedmiotem analizy jest wojna z 2020 r. pomiędzy Armenią a Azerbejdżanem przy silnym militarnym i politycznym zaangażowaniu Turcji. W opracowaniu przedstawiono genezę oraz nakreślono tło historyczne sporu o Górski Karabach, a także wydzielono kilka jego etapów. W kolejnej części tekstu analizie poddano również międzynarodowy wymiar konfliktu, zwracając uwagę na rolę, jaką odegrała Rosja w doprowadzeniu do zaprzestania walk i zawarcia porozumienia pokojowego pomiędzy Baku i Erywaniem. Ponadto omówiono

${ }^{345} \mathrm{~W}$ przypadku Ukrainy to okupacja Krymu i konflikt w Donbasie; Gruzji: nieuznawane Abchazja, Osetia Południowa; Mołdawii: nieuznawane Naddniestrze; Armenii oraz Azerbejdżanu: konflikt w Górskim Karabachu. 
zagadnienie wprowadzenia kontyngentu rosyjskich „sił pokojowych” do Górskiego Karabachu wraz z konsekwencjami z tym związanymi dla regionu Kaukazu Południowego. $\mathrm{W}$ podsumowaniu autorzy wskazali m.in. na czasowy charakter aktualnego uregulowania sporu i możliwość wznowienia walk w przyszłości.

\section{Słowa kluczowe:}

Górski Karabach, Armenia, Azerbejdżan, Rosja, konflikt, wojna

\section{Key words:}

Nagorno-Karabakh, Armenia, Azerbaijan, Russia, conflict, war

\section{Bibliografia:}

1. Adamczewski P., Przywództwo polityczne na poradzieckim obszarze o nieustalonym statusie. Casus Górskiego Karabachu, w: T. Bodio (red.), Kaukaz: mechanizmy legitymacji i funkcjonowania elit politycznych, Tom 7, Warszawa 2012.

2. Алиев счел соглашение по Карабаху капитуляцией Армении, https://www.rbc.ru/politics/10/11/2020/5fa9d8bc9a79471d5963b1e4.

3. Армения заключила мир и пошла на уступки Азербайджану, https://www.rbc.ru/politics/10/11/2020/5fa9b4249a794714efa5ea83.

4. Армения и Азербайджан договорились о гуманитарном перемирии в Карабахе, https://tass.ru/mezhdunarodnaya-panorama/9746921.

5. Армения отвергла посредничество Ирана и Турции в Нагорном Карабахе, https://lenta.ru/news/2020/10/29/bez_nih/.

6. Armenia i Azerbejdżan uzgodniły zawieszenie broni w konflikcie o Górski Karabach, https://www.pap.pl/aktualnosci/news, 733680,armenia-i-azerbejdzan-uzgodnilyzawieszenie-broni-w-konflikcie-o-gorski.

7. Armenia i Azerbejdżan zgodziły się na obecność rosyjskich sił pokojowych w Górskim Karabachu, https://www.pap.pl/aktualnosci/news, 753707,armenia-iazerbejdzan-zgodzily-sie-na-obecnosc-rosyjskich-sil-pokojowych-w.

8. Азербайджан впервые раскрыл потери в войне в Карабахе, https://www.bbc.com/russian/news-55149056

9. В Женеве завершилась встреча глав МИД Армении и Азербайджана, https://iz.ru/1080898/2020-10-30/v-zheneve-zavershilas-vstrecha-glav-mid-armenii-iazerbaidzhana.

10. В ООН подняли вопрос разрушенной инфраструктуры в Карабахе, https://az.sputniknews.ru/karabakh/20210429/426824012/un-karabakh-azerbaijanwar.html

11. Байназаров Э., Лавров А., Часть Шуши: как изменит ход войны в Карабахе потеря города, https://iz.ru/1084341/elnar-bainazarov-anton-lavrov/chast-shushikak-izmenit-khod-voiny-v-karabakhe-poteria-goroda. 
12. Баку и Ереван договорились не обстреливать мирных жителей, https://www.kavkaz-uzel.eu/articles/355942/.

13. Баку ответил на критику из-за помилования офицера-убийцы, https://www.bbc.com/russian/international/2012/08/120831_hungary_azerbaijan_case.

14. Balcerowicz B., Siły zbrojne w stanie pokoju, kryzysu, wojny, Warszawa 2010.

15. Вендик Ю. Армения начинает считать погибших в Карабахе. В Ереване прошел многотысячный марш памяти, https://www.bbc.com/russian/news-54943958

16. Bieleń S., Negocjacje w stosunkach międzynarodowych, Warszawa 2013.

17. Власти Нагорного Карабаха признали утрату контроля над Шуши, https://www.kavkaz-uzel.eu/articles/356278/.

18. Bodio T., Etnokracja w Azji Centralnej, w: T. Bodio, W. Jakubowski (red.), Przywództwo i elity polityczne w krajach WNP, t. 2, Warszawa 2010.

19. Бои в Карабахе. Сводка за 1 октября, https://www.kommersant.ru/doc/4512629.

20. Бои в Карабахе. Сводка за 2 октября https://www.kommersant.ru/doc/4518779.

21. Бои в Карабахе. Сводка за 3 октября, https://www.kommersant.ru/doc/4519221.

22. Бои в Карабахе. Сводка за 4 октября, https://www.kommersant.ru/doc/4519416.

23. Бои в Карабахе. Сводка за 11 октября, https://www.kommersant.ru/doc/4528995.

24. Бои в Карабахе. Сводка за 12 октября, https://www.kommersant.ru/doc/4529640.

25. Бои в Карабахе. Сводка за 13 октября, https://www.kommersant.ru/doc/4530289.

26. Бои в Карабахе. Сводка за 14 октября, https://www.kommersant.ru/doc/4530985.

27. Бои в Карабахе. Сводка за 15 октября, https://www.kommersant.ru/doc/4531624.

28. Бои в Карабахе. Сводка за 16 октября, https://www.kommersant.ru/doc/4537764.

29. Бои в Карабахе. Сводка за 19 октября, https://www.kommersant.ru/doc/4539166.

30. Бои в Карабахе. Сводка за 20 октября, https://www.kommersant.ru/doc/4539808.

31. Бои в Карабахе. Сводка за 21 октября, https://www.kommersant.ru/doc/4540556.

32. Бои в Карабахе. Сводка за 22 октября, https://www.kommersant.ru/doc/4541236.

33. Бои в Карабахе. Сводка за 24 октября, https://www.kommersant.ru/doc/4547686.

34. Бои в Карабахе. Сводка за 25 октября, https://www.kommersant.ru/doc/4548064.

35. Бои в Карабахе. Сводка за 26 октября, https://www.kommersant.ru/doc/4548860.

36. Бои в Карабахе. Сводка за 27 октября, https://www.kommersant.ru/doc/4549548.

37. Бои в Карабахе. Сводка за 28 октября, https://www.kommersant.ru/doc/4550297.

38. Бои в Карабахе. Сводка за 29 октября, https://www.kommersant.ru/doc/4551068

39. Бои в Карабахе. Сводка за 1 ноября, https://www.kommersant.ru/doc/4557414.

40. Бои в Карабахе. Сводка за 2 ноября, https://www.kommersant.ru/doc/4558128.

41. Бои в Карабахе. Сводка за 3 ноября, https://www.kommersant.ru/doc/4558767.

42. Бои в Карабахе. Сводка за 4 ноября, https://www.kommersant.ru/doc/4559094.

43. Бои в Карабахе. Сводка за 5 ноября, https://www.kommersant.ru/doc/4559725.

44. Бои в Карабахе. Сводка за 6 ноября, https://www.kommersant.ru/doc/4564266.

45. Бои в Карабахе. Сводка за 7 ноября, https://www.kommersant.ru/doc/4564566.

46. Бои в Карабахе. Сводка за 8 ноября, https://www.kommersant.ru/doc/4564769.

47. Бондарев Г., Ереван оставил Карабах с демографическими проблемами, https://www.ng.ru/cis/2020-11-13/100_131120.html 
48. Бородихин А. Топор в ЕСПЧ. Суд вынес решение по делу азербайджанского офицера, зарубившего спящего сослуживца-армянина, https://zona.media/article/2020/05/26/axe

49. Bryc A., Rosja w XXI wieku. Gracz światowy czy koniec gry?, Warszawa 2009.

50. Черненко Е., Принуждение к конфликту. Источники “Ъ” рассказали, как Турция готовила почву для обострения в Нагорном Карабахе, https://www.kommersant.ru/doc/4537733.

51. Chawryło K., Górecki W. Górski Karabach: kruchy rozejm, „Analizy OSW”, 202010-12, https://www.osw.waw.pl/pl/publikacje/analizy/2020-10-12/gorski-karabachkruchy-rozejm.

52. Сможет ли Азербайджан вернуть своих беженцев в Карабах?, https://www.bbc.com/russian/news-56660532

53. Cztery samoloty $z$ "mirotworcami" ladowaty w Armenii, https://defence24.pl/czterysamoloty-z-mirotworcami-ladowaly-w-armenii.

54. Czupryński A., Współczesna sztuka operacyjna, Warszawa 2009.

55. Данилов Д., Россия в Закавказье: в поисках мжународной легитимаџии // Б. Коппитерс (ред.), Спорные границы на Кавказе, Брюссель 1996, http://poli.vub.ac.be/publi/ContBorders/rus/.

56. Depczyński M., Elak L., Rosyjska sztuka operacyjna w zarysie, Warszawa 2020.

57. Для армянской сторонь победа - это сохранить свой дом, https://www.kommersant.ru/doc/4538437.

58. Достояние республики. Азербайджанского "убийцу с топором" превратили в героя, https://lenta.ru/articles/2012/09/03/hero/.

59. Дунаевский И., Война без победы, https://rg.ru/2020/09/28/situaciia-v-nagornomkarabahe-prodolzhaet-uhudshatsia.html.

60. Фалалеев М., Дорога домой, В Нагорный Карабах вернулось свыше 50 тысяч беженцев, https://rg.ru/2021/02/23/v-nagornyj-karabah-vernulos-svyshe-50-tysiachbezhencev.html

61. Fedorowicz K., Republika Górskiego Karabachu - atrybuty państwowości a realia polityczne. w: V. Serzhanova, J. Wilk, K. Nowak, J. Plis (red.), Problemy państw nieuznawanych we wspótczesnym świecie, Warszawa 2019.

62. Gadera K., Kaukaz na skraju wojny. Starcia armeńsko-azerbejdżańskie w lipcu 2020, https://www.konflikty.pl/historia/czasy-najnowsze/kaukaz-na-skraju-wojny-starciaarmensko-azerbejdzanskie-2020/.

63. Gągor F., Paszkowski K., Międzynarodowe operacje pokojowe w doktrynie obronnej $R P$, Warszawa-Toruń 1998.

64. Gdzie dwóch się bije, tam ... wygrywa Rosja, „Nowa Europa Wschodnia” 2020, nr 6.

65. Глава МИД Туриии поздравил Баку $с$ «важной победой», https://www.rbc.ru/politics/10/11/2020/5faa30dc9a79473e227c1aee.

66. Голубева А., Атанесян Г., Дергачев В., Козлов П., Семь вопросов к миру в Карабахе. Кто от этого вылирал и что будет дальше? https://www.bbc.com/russian/features-54896303. 
67. Górecki W., Górski Karabach: Azerbejdżan na drodze do zwycięstwa, „Analizy OSW", 2020-11-09, https://www.osw.waw.pl/pl/publikacje/analizy/2020-1109/gorski-karabach-azerbejdzan-na-drodze-do-zwyciestwa.

68. Górecki W., Górski Karabach: początek wojny pozycyjnej, „Analizy OSW”, 2020-0930 https://www.osw.waw.pl/pl/publikacje/analizy/2020-09-30/gorski-karabachpoczatek-wojny-pozycyjnej (współpraca: Chawryło K., Chudziak M.).

69. Górecki W., Górski Karabach: sukcesy militarne Azerbejdżanu, „Analizy OSW”, 2020-10-20, https://www.osw.waw.pl/pl/publikacje/analizy/2020-10-20/gorskikarabach-sukcesy-militarne-azerbejdzanu.

70. Górecki W., Górski Karabach: kluczowa faza azerbejdżańskiej ofensywy, „Analizy OSW" 2020-11-06, https://www.osw.waw.pl/pl/publikacje/analizy/2020-11-06/gorskikarabach-kluczowa-faza-azerbejdzanskiej-ofensywy.

71. Górecki W., Kaukaski węzeł gordyjski. Konflikt o Górski Karabach, Raport OSW, Maj 2020.

72. Górecki W., Górski Karabach: normalizacja pelna niewiadomych, „Analizy OSW” 2020-11-26,

73. https:/www.osw.waw.pl/pl/publikacje/analizy/2020-11-26/gorski-karabachnormalizacja-pelna-niewiadomych.

74. Górecki W., Nowa odstona konfliktu o Górski Karabach, „Analizy OSW” 2020-0928, https://www.osw.waw.pl/pl/publikacje/analizy/2020-09-28/nowa-odslonakonfliktu-o-gorski-karabach.

75. Górecki W., Wojna w Górskim Karabachu: wzrost przewagi Azerbejdżanu, „Analizy OSW" 2020-10-05, https://www.osw.waw.pl/pl/publikacje/analizy/2020-1005/wojna-w-gorskim-karabachu-wzrost-przewagi-azerbejdzanu.

76. Górecki W., Górski Karabach: wojna z dyplomacja w tle, „Analizy OSW” 2020-1029, https://www.osw.waw.pl/pl/publikacje/analizy/2020-10-29/gorski-karabachwojna-z-dyplomacja-w-tle.

77. Górecki W., Rywalizacja poprzez wspótpracę. Rosyjsko-tureckie centrum obserwacyjne na Kaukazie, „Analizy OSW" 2021-02-02, https://www.osw.waw.pl/pl/publikacje/analizy/2021-02-02/rywalizacja-poprzezwspolprace-rosyjsko-tureckie-centrum-obserwacyjne.

78. Информационный бюллетень Министерства обороны Российской Федерации о деятельности российского миротворческого контингента в зоне нагорнокарабахского конфликта, https://mil.ru/russian_peacekeeping_forces/news/more.htm?id=12364074@egNews.

79. Иран предложил план урегулирования в Карабахе с участием России и Турции,

80. https://ria.ru/20201030/karabakh-1582253303.html.

81. Jarosiewicz A., Falkowski M., Wojna czterodniowa w Górskim Karabachu, „Analizy OSW", 2016-04-06, https://www.osw.waw.pl/pl/publikacje/analizy/2016-0406/wojna-czterodniowa-w-gorskim-karabachu.

82. Jurasz W., Z małej wojny na dalekim Kaukazie wypływaja ważne wnioski dla Polski, https://wiadomosci.onet.pl/swiat/walki-w-gorskim-karabachu-jurasz-wazne-wnioskidla-polski/kj9shje

83. Карабах: хроника войны-2020, https://www.kavkaz-uzel.eu/articles/354861/. 
84. Koniec status quo? Azerska rekonkwista Górskiego Karabachu, Ośrodek Studiów Przestrzeni Postsowieckiej, Analiza OSPP 48, 07.10.2020, https://www.wojskopolskie.pl/aszwoj/u/9f/68/9f68ba0b-907e-4b3c-ad30-

ed8ae23448d6/analiza_ospp_pazdziernik_2020_-

_koniec_status_quo_azerska_rekonkwista_gorskiego_karabachu.pdf.

85. Kardaś S., Rola elit politycznych $w$ konfliktach na obszarze WNP (na przykladzie armeńsko-azerbejdżánskiego sporu o Górski Karabach w: T. Bodio (red.), Kaukaz: mechanizmy legitymacji i funkcjonowania elit politycznych, t. 7, Warszawa 2012.

86. Konarzewska N., Rola nacjonalizmu w azersko-ormiańskim sporze wokót Górskiego Karabachu, „Studia politologiczne” 2012, vol., 23.

87. Коваленко М., Переговорно-карабахский конфликт, https://www.kommersant.ru/doc/4556864.

88. Лавров заявил о необходимости присутствия миротворчев в Карабахе, https://www.gazeta.ru/politics/news/2020/10/14/n_15078739.shtml.

89. Лавров заявил о неполном соблюдении режима прекращения огня в Карабахе,

90. https://iz.ru/1072648/2020-10-12/lavrov-zaiavil-o-nepolnom-sobliudenii-rezhimaprekrashcheniia-ognia-v-karabakhe.

91. Legieć A., Perspektywy rozwiąania konfliktu o Górski Karabach, Biuletyn PISM, 2019-11-29, nr 168 (1963), https://pism.pl/publikacje/Perspektywy_rozwiazania_konfliktu_o_Gorski_Karabach_.

92. Legucka A., Operacja pokojowa Rosji w Górskim Karabachu - cele $i$ wyzwania, „Biuletyn PISM”, 2021-01-29, 2 nr https://pism.pl/publikacje/Operacja_pokojowa_Rosji_w_Gorskim_Karabachu_cele_ i_wyzwania.

93. Мадридские принцииы, https://www.kavkaz-uzel.eu/articles/160309/.

94. Маркедонов С., Нагорный Карабах - 2018: война, мир или балансирование на грани?, Аналитические статьи, Российский совет по международным делам, https://russiancouncil.ru/analytics-and-comments/analytics/nagornyy-karabakh-2018voyna-mir-ili-balansirovanie-na-grani/

95. Маркедонов С., Тридиать лет нагорно-карабахского конфликта: основные этапы и перспективы урегулирования, «Постсоветские исследования» 2018, t. 1.

96. Маркедонов С., Каледжи В., Хас К., Слом статус-кво и международное измерение кризиса в Нагорном Карабахе. Доклад Международного дискуссионного клуба «Валдай», Декабрь 2020, https://ru.valdaiclub.com/files/36258/.

97. Məzun A.A., Economic impact of peacekeeping forces and the case of Karabakh,

98. Topchubashov Center, https://top-center.org/en/analytics/3084/economic-impact-ofpeacekeeping-forces-and-the-case-of-karabakh.

99. Parafianowicz Z., Wojna o Karabach i sojusze, które nie miały prawa zaistnieć, Parafianowicz: Wojna o Karabach i sojusze, które nie miały prawa zaistnieć GazetaPrawna.pl.

100. Pax Russo-Turcica. Stosunki rosyjsko-tureckie po wojnie o Górski Karabach, Centrum Badań nad Bezpieczeństwem Akademii Sztuki Wojennej, Raport OSPP, Warszawa 2021; https:/www.wojsko-polskie.pl/aszwoj/u/84/49/84491f38-f859-45f1- 
9a6f-

84b65011aa92/ospp_raport_marzec_2021_pax_russo_turcica_stosunki_rosyjsko_ture ckie_po_wojnie_o_gorski_karabach.pdf.

101. Помпео заявил, что проведет 23 октября переговоры с главами МИД Азербайджана и Армении, https://tass.ru/mezhdunarodnaya-panorama/9779603.

102. Поплавский А., Война в Карабахе: как конфликт Еревана и Баку бьет по Тегерану, https://www.gazeta.ru/politics/2020/10/28_a_13336159.shtml.

103. П Путин пригласил глав МИДов Азербайджана и Армении на переговоры в Москву, https://www.kommersant.ru/doc/4522178\#id1962787.

104. Путин, Трамп и Макрон согласовали заявление по ситуачии в Нагорном Kapaбaxe,

105. https://iz.ru/1068016/2020-10-01/putin-tramp-i-makron-soglasovali-zaiavleniepo-situatcii-v-nagornom-karabakhe.

106. Rokita Z., Historia konfliktu górskokarabaskiego i jego miejsce $w$ polityce zagranicznej Federacji Rosyjskiej, „Pisma Humanistyczne” 2010, nr 7.

107. Российский миротворческий контингент в Нагорном Карабахе, $\mathrm{http} / / /$ mil.ru/russian_peacekeeping_forces.htm.

108. Strachota K., Ostre walki między Armeniq i Azerbejdżanem, „Analizy OSW" 2020-07-16, https:/www.osw.waw.pl/pl/publikacje/analizy/2020-07-16/ostre-walkimiedzy-armenia-i-azerbejdzanem.

109. Тарасенко П., Нагорный Карабах дождался перемирия, https://www.kommersant.ru/doc/4528751\#id1962787.

110. Терминь МЧС России, https://www.mchs.gov.ru/ministerstvo/oministerstve/terminy-mchs-rossii/term/2704.

111. Thompson E.M., Trubadurzy imperium. Literatura rosyjska $i$ kolonializm, tłum. A. Sierszulska, „Horyzonty Nowoczesności” 2000, t. 8.

112. Turcy wchodza na Kaukaz. Jest porozumienie $z$ Rosjanami, https://warsawinstitute.org/pl/turcy-wchodza-na-kaukaz-jest-porozumienie-zrosjanami/.

113. UNHCR o możliwości popetnienia zbrodni wojennych w Górskim Karabachu, https://www.pap.pl/aktualnosci/news, 749128, unhchr-o-mozliwosci-popelnieniazbrodni-wojennych-w-gorskim-karabachu.html.

114. Захаров В.А., Арешев А.Г., Майендорфская Декларачия 2 ноября 2008 года и ситуачия вокруг Нагорного Карабаха. Сборник статей, Москва 2009.

115. Заявление Президента Азербайджанской Республики, Премьер-министра Республики Армения иПрезидента Российской Федерачии, http://kremlin.ru/events/president/news/64384.

116. Zieliński J., Konflikt o Górski Karabach i próby jego rozwiąania, „Annales Universitatis Paedagogicae Cracoviensis. Studia Politologica” 2014, nr. 12.

117. Zięba R., Funkcjonowanie paneuropejskiego mechanizmu bezpieczeństwa KBWE/OBWE, „Studia Europejskie” 1998, nr 3.

118. Żarkowski P., Zasady użycia sit zbrojnych $w$ operacjach pokojowych, „Doctrina. Studia społeczno-polityczne” $2015, \quad$ nr 12 ; 